\title{
ZARYS DZIEJÓW PARAFII POPKOWICE DO POCZĄTKÓW XVII WIEKU
}

\section{Powstanie parafii}

Mimo, że nie zachowały się ani dokument fundacyjny, ani erekcyjny parafii popkowickiej możemy z bardzo dużą pewnością ustalić czas jej powstania. Pozwala na to zapis zawarty w spisanym przez Jana Długosza Katalogu biskupów krakowskich. Informuje on, że biskup krakowski Piotr Wysz, na prośby sędziego krakowskiego Michała z Chmielowa, herbu Półkozic, uposażył w dziesięciny snopowe ze wsi Kierz, należące dotąd do dochodów biskupich, fundowany w tym czasie kościół w Popkowicach ${ }^{1}$. Pontyfikat Piotra Wysza na biskupstwie krakowskim (1392-1412)2, a zwłaszcza okres pełnienia funkcji sędziego ziemskiego krakowskiego przez Michała z Chmielowa (1397-1403) ${ }^{3}$, pozwalają stosunkowo precyzyjnie datować fundację parafii popkowickiej. W sposób oczywisty musiała ona przypadać na czasy, gdy Michał był sędzią krakowskim. Nie budzi to żadnych wątpliwości i było już wielokrotnie odnotowane w literaturze ${ }^{4}$.

* Jacek Chachaj - dr hab. historii; profesor w Instytucie Historii, Katolicki Uniwersytet Lubelski Jana Pawła II; e-mail: chachaj@kul.pl

ORCID 0000-0002-2268-9692

${ }^{1}$ Pomniki Dziejowe Polski, seria II, t. 10, cz. 2: Katalogi biskupów krakowskich, wyd. J. Szymański, Warszawa 1974, s. 125.

${ }^{2}$ S. Trawkowski, Piotr z Radolina, zwany Wyszem, h. Laski (zm. 1414), w: Polski Stownik Biograficzny (dalej: PSB), t. 26, Wrocław-Warszawa-Kraków-Gdańsk-Łódź 1981, s. 423, 427; P. Nitecki, Biskupi Kościoła w Polsce. Stownik biograficzny, Warszawa 1992, s. 166-167; T. Graff, Piotr Wysz, Piotr z Radolina, w: Encyklopedia Katolicka, t. 15, Lublin 2011, kol. 690.

${ }^{3}$ Z. Perzanowski, Michat z Bogumiłowic, określany także z Chmielowa i z Czyżowa, PSB, t. 20, Wrocław-Warszawa-Kraków-Gdańsk 1975, s. 619.

${ }^{4} \mathrm{H}$. Grocholski, Sieć parafialna archidiakonatu archidiakonatu zawichojskiego do końca XVI w., Lublin 1956 (mps Archiwum KUL), s. 44, 71 (autor określił czas powstania parafii na lata 1395-1403); Katalog zabytków sztuki w Polsce (dalej: KZSP), t. 8: Województwo lubelskie, pod red. R. Brykowskiego, E. Rowińskiej i Z. Winiarz, z. 9: Powiat kraśnicki, inwentaryzację przeprowa- 
Postawioną wyżej tezę zdaje się także potwierdzać zupełny brak parafii Popkowice w czternastowiecznych aktach Kamery Apostolskiej (spisach beneficjów, z których pobierano dziesięcinę papieską, oraz wykazach świętopietrza płaconego przez parafie) $)^{5}$. Akta te, dotyczące lat 1325-1375, uchodzą za bardzo rzetelne i niemal kompletne. Skoro zatem parafia Popkowice ani razu nie pojawiła się w tych źródłach, to należy przyjąć, że jeszcze wtedy nie istniała.

Dodatkowo istnieją bardzo poważne przesłanki, by przyjąć, że jeszcze w początku lat 90 . XIV wieku nie istniały plany powoływania do życia parafii w Popkowicach. Świadczy o tym treść pochodzącego z 7 stycznia 1391 roku dokumentu, wystawionego przez ówczesnego dziedzica wsi Wydżgę, w którym uposażył on kościół parafialny w Czyżowie (którego także był właścicielem) ${ }^{6}$. Wśród dochodów, które miała otrzymywać czyżowska świątynia znalazły się także dziesięciny z Popkowic ${ }^{7}$. W świetle informacji pochodzących z późniejszego okresu wydaje się, że wspomniane dziesięciny mogły być jedynie dziesięcinami z łanów należących do folwarku, a zatem dziesięcinami swobodnymi, których cel wskazywał właściciel wsi. Zdaje się to potwierdzać fakt, że nie znajdujemy ich w pochodzących z XV i XVI wieku opisach uposażenia parafii w Czyżowie ${ }^{8}$. Można to wytłumaczyć w prosty sposób zmianą odbiorcy dziesięcin swobodnych, dokonaną zapewne w momencie fundowania parafii popkowickiej. Nie mogło też raczej, w przypadku dziesięcin wspomnianych w 1391 roku, chodzić o wykazujące

dziły I. Galicka i E. Rowińska, Warszawa 1961, s. 28 (gdzie bez podania uzasadnienia, być może za H. Grocholskim czas powstania kościoła określono także na lata 1395-1403); A. Sochacka, Jan z Czyżowa namiestnik Władysława Warneńczyka. Kariera rodziny Półkozów w średniowieczu, Lublin 1993, s. 60 (we wcześniejszych pracach badaczka datowała powstanie parafii na lata 1392-1412, czyli na czas sprawowania funkcji biskupa przez Piotra Wysza: A. Sochacka, Własność ziemska w województwie lubelskim w średniowieczu, Lublin 1987, s. 87); A. Wnuk, Dzieje parafii Popkowice. 600 lat historii, Urzędów 2004, s. 14; K. Krakowiak, Krótka historia parafii Św. Trójcy w Popkowicach (http://xoomer.virgilio.it/mpelak/dokumenty/histparpopko.htm (dostęp:16.03.2017)..

${ }^{5}$ Spisy beneficjów, w tym parafii, należących do archidiakonatu zawichojskiego, do którego należała później parafia popkowicka, nie dla wszystkich przekrojów czasowych są kompletne. Nie wydaje się jednak możliwe, by została ona przypadkowo pominięta, bo część wykazów jest niemal na pewno pełna: Monumenta Poloniae Vaticana (dalej: MPV), t. 1: Akta Kamery Apostolskiej (dalej: ACA), vol. 1: 1207-1344, wyd. J. Ptaśnik, Kraków 1913, s. 158-160, 233-235, 311-312, 353, 355, 377, 388, 397-398; t. 2: ACA, vol. 2: 1344-1374, wyd. J. Ptaśnik, Kraków 1913, s. 173, 177, 179, 181, 183-184, 186, 190, 198, 207, 217, 226-227, 237, 246, 255, 263, 270, 278, 286, 294, 300, 361363, 383, 401, 417, 430, 438; t. 9: ACA, vol. 3: Księga kolektora papieskiego Piotra syna Stefana 1373-1375, wyd. S. Szczur, Kraków 1994, s. 19-20, 39.

${ }^{6}$ Zbiór dokumentów małopolskich (dalej: ZDM), cz. 4: 1211-1400, wyd. S. Kuraś i I. Sułkowska-Kuraś, Wrocław-Warszawa-Kraków 1969, nr 1095, s. 250-252. Więcej o Wyżdze z Czyżowa: J. Wroniszewski, Nobiles Sandomirienses. Rody Dębnów, Janinów, Grzymałów, Doliwów i Powalów, Kraków 2013, s. 82-84.

${ }^{7}$ Tamże, s. 251; A. Sochacka, Własność, s. 25; taż, Jan z Czyżowa, s. 58.

${ }^{8}$ J. Długosz, Liber beneficiorum dioecesis Cracoviensis (dalej: DLB), wyd. A. Przeździecki, t. 1, Kraków 1863, s. 342; t. 2, Kraków 1864, s. 494, 512-513; Księga dochodów beneficjów diecezji krakowskiej z roku 1529 (tzw. Liber retaxationum) (dalej: LR 1529), wyd. Z. Leszczyńska-Skrętowa, Wrocław-Warszawa-Kraków 1968, s. 452, 461. 
się znacznie większą trwałością dziesięciny z łanów kmiecych. Wszystko wskazuje na to, że już wtedy dziesięciny łanów kmiecych w Popkowicach należały do scholastyka sandomierskiego, a ponadto nie mógł nimi dysponować dziedzic wsi. W każdym razie nie wydaje się prawdopodobne, aby przeznaczano dziesięciny z Popkowic na rzecz kościoła istniejącego $\mathrm{w}$ innej wsi, gdyby istniały plany fundacji parafii w samych Popkowicach.

Sytuacja uległa zmianie, gdy krótko po 1391 roku Czyżów i Popkowice przeszły, wraz z innymi posiadłościami Wydżgi z Czyżowa, w ręce podsędka krakowskiego Michała z Bogumiłowic herbu Półkozic. Stało się to być może w następstwie małżeństwa zawartego przez Michała z nieznaną nam córką Wydżgi ${ }^{9}$. Nowy właściciel wykazał się, co prawda, troską o parafię w Czyżowie wznosząc tam murowany kościół ${ }^{10}$, ale, inaczej niż poprzedni właściciel, podjął prawdopodobnie także działania w celu utworzenia nowej parafii z ośrodkiem w Popkowicach. Zapewne po objęciu funkcji sędziego ziemskiego krakowskiego, co nastąpiło w 1397 roku $^{11}$, uzyskał od biskupa krakowskiego Piotra Wysza zgodę na nadanie nowemu kościołowi dziesięcin snopowych ze wsi Kierz. Należy się spodziewać, że były to dziesięciny z nowizn, a zatem wchodziły do dochodów biskupa. Ich pozyskanie umożliwiło przeprowadzenie fundacji, choć w późniejszym czasie nie znajdujemy tych dziesięcin wśród dochodów kościoła popkowickiego ${ }^{12}$.

Przyczyny fundacji nowej parafii w Popkowicach można umieścić w kontekście szerszych procesów historycznych, które w tym okresie miały miejsce na obszarach diecezji krakowskiej położonych na wschód od Wisły. Porozumienie zawarte przez panów krakowskich z Wielkim Księciem Litewskim Jagiełłą, które zaowocowało objęciem przez niego tronu polskiego, zupełnie zmieniło sytuację tych terenów. $Z$ pogranicza narażonego na stałe zagrożenie najazdami ze wschodu, stały się rejonem położonym niemal w samym centrum rozległego państwa Władysława Jagiełły ${ }^{13}$. Dodatkowo ich znaczenie podnosił fakt, że przez Lublin przebiegała trasa stałych podróży władcy z Krakowa na Litwę, wynikających $\mathrm{z}$ charakteru zarządzania państwem. Wygaśnięcie stałego zagrożenia najazdami przyczyniło się jednocześnie do ożywienia procesów osadniczych oraz handlu na wschodnich krańcach Małopolski. Skutkiem tych wszystkich zjawisk był wzrost

${ }^{9}$ Sochacka, Jan z Czyżowa, s. 58-60. Hipotezę o uzyskaniu przez Michała z Bogumiłowic wspomnianych dóbr przez małżeństwo z nieznaną córką Wydżgi, być może jedyną dziedziczką jego posiadłości, wysunęła Anna Sochacka. Zauważyła ona, że po Michale Popkowice przejęła jego córka Wichna, od której wieś w 1417 roku odkupił syn Michała - Jan z Czyżowa, brat Wichny. Mogło to wynikać z prawa wykupu przez braci dóbr macierzystych przypadających ich siostrom. Tamże, s. 60, 195. Wcześniej badaczka uważała Michała za syna Wydżgi: Sochacka, Własność, s. 87. Hipotezę o tym, że Wyżga z Czyżowa mógł być teściem Michała z Bogumiłowic zdecydowanie poparł Jan Wroniszewski, stwierdzając nawet, że jest to niemal pewne: Wroniszewski, Nobiles, s. 83.

${ }^{10}$ DLB, t. 2, s. 494.

${ }^{11}$ Z. Perzanowski, Michat, s. 619.

${ }^{12}$ W XV i XVI wieku dziesięciny z wsi Kierz należały do plebana z Wojciechowa. LR 1529, s. 439; Dzieje Lubelszczyzny, t. 3: Stownik historyczno-geograficzny województwa lubelskiego w średniowieczu, opr. S. Kuraś, Warszawa 1983 (dalej: SHGWL), s. 100.

${ }^{13} \mathrm{~S}$. Litak, Powstanie organizacji parafialnej a rozwój osadnictwa w ziemi łukowskiej XII-XVI wieku, „Roczniki Humanistyczne” (dalej: RH), 48 (2000) z. 2 (specjalny), s. 284. 
zaludnienia tego terenu, powstawanie nowych i odnawianie dawnych osad, oraz wzrost aktywności gospodarczej rodów, które już od 1. połowy XIV wieku otrzymywały od władców nadania ziemskie we wschodniej części ówczesnego województwa sandomierskiego ${ }^{14}$.

Należy pamiętać, że powstanie parafii oznaczało zdecydowane podkreślenie odrębności jej obszaru, a także zamieszkującej go ludności. Parafia stanowiła bowiem nie tylko podstawowy szczebel organizacji i administracji Kościoła, ale także, a może przede wszystkim, pewną silnie powiązaną społecznie i gospodarczo grupę osób. W przypadku, gdy znaczna część, a czasem całość obszaru parafii należała do jednego właściciela (tak było w przypadku Popkowic), był on panem wszystkich członków lokalnej społeczności. Także właściciel, jako posiadacz prawa patronatu, decydował o obsadzie beneficjum plebańskiego, dysponując prawem prezenty, czyli przywilejem przedstawiania osoby, która decyzją biskupa zostawała plebanem. Dawało mu to szczególnie istotną rolę w strukturze społecznej parafii ${ }^{15}$. W szystko to stanowiło zapewne wystarczającą zachętę do podejmowania działalności fundacyjnej, choć nie można także wykluczyć, że ważną przyczyną powstawania nowych parafii stanowiły pobudki dewocyjne, czyli osobista religijność fundatorów. W każdym razie wyraźnie daje się zaobserwować $\mathrm{w}$ ostatnich latach XIV, oraz pierwszych dekadach XV wieku wzrost liczby parafii na położonych na wschód od Wisły terenach diecezji krakowskiej ${ }^{16}$.

Wydaje się, że to, co wiemy o początkach parafii Popkowice dobrze wpisuje się w zarysowany wyżej kontekst wydarzeń. Michał z Bogumiłowic, występujący jako Michał z Czyżowa od momentu, gdy został właścicielem tej ostatniej miejscowości, postanowił zapewne podkreślić odrębność przejętych przez siebie dóbr popkowickich ${ }^{17}$. Wydaje się, że na przełomie XIV i XV wieku sąsiadowały one od wschodu i zachodu z dobrami królewskimi (na wschodzie z kompleksem dóbr, których centrum stanowił Wilkołaz, na zachodzie z dobrami dzierzkowickimi), od południa ze sporym kompleksem dóbr kraśnickich, które w 1377 roku, mocą nadania Ludwika Węgierskiego, przeszły w ręce Dymitra z Goraja i jego następ-

${ }^{14}$ Szersze tło tego zjawiska przedstawiła Anna Sochacka: Sochacka, Własność, s. 22n.

${ }^{15}$ Więcej o roli patrona w społeczności parafialnej w średniowieczu: E. Wiśniowski, Parafie $w$ średniowiecznej Polsce. Struktura i funkcje spoteczne, Lublin 2004, s. 167-175.

${ }^{16} \mathrm{~W}$ ziemi łukowskiej do schyłku XIV wieku powstały tylko trzy parafie. Od początku XV wieku do końca panowania Władysława Jagiełły na jej obszarze, oraz na przyległych do niej wschodnich krańcach ziemi stężyckiej podjęto próby powołania do życia pięciu kolejnych: Litak, Powstanie organizacji, s. 284, 287-290, 295, 297-298, 301. Na terenie archidiakonatu lubelskiego już na ostatnich 12 lat XIV wieku przypadły fundacje czterech (a może nawet pięciu) nowych parafii. Dla rozważań o początkach parafii Popkowice znamienny jest przykład parafii fundowanej w tym okresie w Woli Witowskiej (późniejszej Końskowoli), gdzie dziesięciny na rzecz kościoła także przekazał biskup Piotr Wysz, a świątynia posiadała to samo, co w Popkowicach wezwanie - Św. Krzyża: J. Chachaj, Bliżej schizmatyków niż Krakowa. Archidiakonat lubelski w XV i XVI wieku, Lublin 2012, s. 78 (wraz z przypisem 12). Do końca panowania Władysława Jagiełły na terenie archidiakonatu lubelskiego powstało zapewne 14-15 nowych parafii (z czego trzy na zachód od Wisły, a w tej grupie Sienno uposażone przez Piotra Wysza z kościołem Św. Krzyża, oraz Ciepielów z kościołem o tym samym wezwaniu): Chachaj, Bliżej schizmatyków, s. 78-81.

${ }^{17}$ Zwracano już na to uwagę: Sochacka, Jan z Czyżowa, s. 69. 
ców $^{18}$, zaś od północy z należącym do szlachty Łopiennikiem ${ }^{19}$. Można zatem przypuszczać, że jeszcze za panowania Kazimierza Wielkiego niemal wszystkie ziemie otaczające Popkowice wchodziły w skład domeny królewskiej. Sytuacja uległa zmianie w efekcie nadań dokonanych w okresie rządów Andegawenów. Na ten czas przypadły zapewne także pierwsze działania odbiorców nadań zmierzające do zagospodarowania nowych posiadłości (np. w przypadku dóbr kraśnickich nastąpiła lokacja miejska Kraśnika i przeniesienie do tego nowego centrum klucza dóbr siedziby parafii, która wcześniej funkcjonowała w oddalonej o kilka kilometrów na południowy wschód Stróży ${ }^{20}$ ). Krótko potem podjęto także kroki zmierzające do stworzenia nowego ośrodka pozostających w rękach królewskich dóbr leżących na zachód od Popkowic, co zaowocowało lokacją Urzędowa i powołaniem tam do życia nowej parafii w początkach XV wieku ${ }^{21}$. Nie wiemy, kiedy dokładnie Wydżga z Czyżowa otrzymał Popkowice. Stało się to jednak na przełomie lat 80 . i 90 . XIV wieku, gdy przyszłość terenów położonych na wschód od Wisły wciąż wydawała się niejasna. Dodatkowo Popkowice wydają się w tym okresie niewielką posiadłością rycerską otoczoną dużymi kompleksami dóbr królewskich oraz możnowładczych. W ciągu kilku lat nastąpiły zasadnicze zmiany. Wstąpienie na tron Jagiełły oraz przejście Popkowic w ręce człowieka, którego ambicje, wpływy polityczne, a następnie także majątek były większe niż poprzednika, a dodatkowo także stale rosły, całkowicie zmieniły sytuację. Dodatkowym atutem Popkowic była także ich lokalizacja w pobliżu Urzędowa, będącego stolicą powiatu. Zauważono bowiem, że Michał z Czyżowa inwestował w posiadłości znajdujące się w pobliżu ważnych ośrodków administracji oraz szlaków handlowych ${ }^{22}$.

Nie powinny więc dziwić działania podjęte przez Michała z Czyżowa po nabyciu Popkowic. Zapewne także należy się domyślać, że właśnie z tymi działaniami powinniśmy wiązać odkupienie przez niego od Trojana z Gościeradowa w 1403 roku części sąsiadujących z Popkowicami Skorczyc ${ }^{23}$, które stały się od-

${ }^{18}$ Kodeks dyplomatyczny Małopolski (dalej: KDM), wyd. F. Piekosiński, t. 3: 1333-1386, Kraków 1887, nr 893, s. 310-311; Sochacka, Własność, s. 27, gdzie także przedstawiona dyskusja na temat czasu nadania.

${ }^{19}$ SHGWL, s. 138.

${ }^{20}$ R. Dobroć, Pierwsze wieki parafii pod wezwaniem Wniebowzięcia Najświętszej Marii Panny w Kraśniku, Lublin 2015 (mps Archiwum KUL), s. 74-78, gdzie także odniesienia do wcześniejszej literatury.

${ }^{21} \mathrm{R}$. Szczygieł, Lokacja miasta na prawie niemieckim i jego dzieje $w$ czasach jagiellońskich, w: Dzieje Urzędowa, red. R. Szczygieł, M. Surdacki, Urzędów 2011, s. 55, 62, 93.

${ }^{22}$ Posiadał on Działoszyce, które leżały przy drodze łączącej Lwów z Krakowem i Śląskiem; Chmielów, który znajdował się stosunkowo blisko Wiślicy, Korczyna i Krakowa; Czyżów położony niedaleko Sandomierza i Zawichostu, oraz dodatkowo przy drodze do Opatowa; Popkowice leżały pod Urzędowem, a Bystrzyca pod Lublinem. Jednocześnie większość wymienionych dóbr znajdowała się blisko szlaku, który za panowania Władysława Jagiełły zyskał wielkie znaczenie łącząc Małopolskę z Litwą, wiodącego przez przeprawę w Zawichoście, Urzędów i Lublin. Sochacka, Jan z Czyżowa, s. 62.

${ }^{23}$ Sochacka, Własność, s. 25; taż, Jan z Czyżowa, s. 60. Druga część wsi, określana jako jej połowa, została w 1405 roku włączona przez Władysława Jagiełłę w skład Urzędowa. ZDM, cz. 6: Dokumenty króla Władysława Jagietly z lat 1386-1417, wyd. I. Sułkowska-Kuraś i S. Kuraś, 
tąd na trwałe częścią powiązanego z Popkowicami kompleksu własnościowego ${ }^{24}$. $\mathrm{Z}$ dużą dozą pewności możemy stwierdzić, że podobnie, jak fundacja nowej parafii, była to próba wzmocnienia gospodarczego dóbr popkowickich. Prawdopodobnie nie pomylimy się też, jeśli będziemy dostrzegać niemal ścisły związek chronologiczny tej transakcji z powstaniem parafii popkowickiej. Możemy przypuszczać, że prawdopodobnie niemal od początku jej istnienia, niezależnie od precyzyjnej daty formalnego erygowania parafii przez biskupa, Skorczyce (a przynajmniej kupiona przez Michała z Czyżowa część tej wsi) weszły w jej skład.

\section{Wcześniejsza przynależność parafialna Popkowic}

W tym miejscu warto zadać pytanie o wcześniejszą przynależność parafialną Popkowic (jak wiemy wieś istniała zanim powstała mająca w niej swoje centrum parafia). Z rozważań niemal na pewno powinniśmy wykluczyć sąsiadujące z Popkowicami od wschodu i północy, istniejące już w XIV wieku, parafie Wilkołaz i Ratoszyn ${ }^{25}$, przede wszystkim dlatego, że należały one do archidiakonatu lubelskiego. W przypadku, gdyby Popkowice wchodziły wcześniej w skład którejś $\mathrm{z}$ nich zapewne także parafia popkowicka podlegałaby tej jednostce administracji kościelnej. Ponieważ jednak zawsze należała ona do archidiakonatu zawichojskiego ${ }^{26}$ przyjęcie założenia, że wyłoniła się z którejś z parafii archidiakonatu lu-

Wrocław-Warszawa-Kraków-Gdańsk 1974, nr 1680, s. 239-241; SHGWL, s. 212. Już w 1395 roku występował Wisław ze Skorczyc, określony jako dziedzic tej wsi: ZDM, cz. 4, nr 1118, s. 286; Sochacka, Własność, s. 25; taż, Jan z Czyżowa, s. 60. Może to oznaczać, że była to już wówczas wieś szlachecka, którą później częściowo przejął król, albo też, że jej część przez cały czas pozostawała w rękach monarszych: Sochacka, Własność, s. 25. Nie jest jasne w jaki sposób w posiadanie części Skorczyc wszedł Trojan z Gościeradowa, zapewne tożsamy z poświadczonym w latach 1409-1418 dziedzicem Gościeradowa: SHGWL, s. 79; Sochacka, Własność, s. 204.

${ }^{24}$ Sochacka, Własność, s. 178.

${ }^{25}$ Parafia z centrum w Wilkołazie jest potwierdzona źródłowo od 1325 roku (MPV, t. 1: ACA, vol. 1, s. 173), a istnieją przesłanki, by jej powstanie przenosić w okres znacznie wcześniejszy, XIII, lub nawet schyłek XII wieku (J. Chachaj, Najstarsze kościoły lubelskie, w: Ziemia - Człowiek Sztuka. Interdyscyplinarne studia nad ziemiq. Archeologia, historia, kultura, sztuka, red. U. Mazurczak, Lublin 2015, s. 388-389, gdzie także odsyłacze do literatury). Parafia ratoszyńska istniała bez wątpienia w 1328 roku (MPV, t. 1: ACA, vol. 1, s. 309), choć część badaczy była skłonna uznać, że funkcjonowała przynajmniej kilka lat wcześniej (P. Szafran, Rozwój średniowiecznej sieci parafialnej w Lubelskiem, Lublin 1958, s. 163-164).

${ }^{26}$ LR 1529, s. 452; Archiwum Krakowskiej Kapituły Katedralnej (AKKK), sygn. tymcz. I-27 (sygn. dawna nr 5): tzw. Liber contributionis (1561) (dalej: LC 1561), k. 71v; AKKK, sygn. tymcz. I-26 (sygn. dawna nr 6): tzw. Liber contributionis (1577) (dalej: LC 1577), k. 129v; Archiwum Kurii Metropolitalnej w Krakowie (AKMK), sygn. AV 1: Wizyta w archidiakonacie zawichojskim Andrzeja z Żarnowa wikariusza kolegiaty sandomierskiej z r. 1592 z polecenia Marcina Szyszkowskiego archidiakona zawichojskiego, kanonika krakowskiego, prepozyta iłżeckiego (dalej: Wizytacja 1592), s. 43; AKKK, depozyt w AKMK, sygn. nr 12: Visitatio ecclesiarum in archidiakonatu Zavichostensi AD 1598 (dalej: Wizytacja 1598), s. 44; W. Kowalski, Schematyzm diecezji krakowskiej $z$ tzw. kopiarza wiślickiego, „Archiwa, Biblioteki i Muzea Kościelne”, 81 (2004) s. 116; AKKK, depozyt w AKMK, sygn. nr 34 (AVCap 34): Acta visitationis ecclesiarum archidiakonatus Zavicho- 
belskiego zmuszałoby nas do wyjaśnienia przyczyn tej zaskakującej i nietypowej zmiany przynależności administracyjnej. Z kolei spośród istniejących w pobliżu Popkowic parafii archidiakonatu zawichojskiego, rozważać możemy ich wcześniejszą przynależność jedynie do dwóch parafii, które istniały już w 1325 roku - Dzierzkowic lub Stróży ${ }^{27}$. W literaturze pojawiła się teza, że parafia z ośrodkiem w Popkowicach została wyodrębniona być może z parafii dzierzkowickiejer. Pogląd ten wydaje się prawdopodobny, choć przesłanka, na której został oparty jest wątpliwa $^{29}$. Za równie prawdopodobną należy uznać wcześniejszą przynależność Popkowic do parafii Stróża, której centrum znajdowało się bliżej, a obraz sieci drożnej, który wyłania się z opracowań kartograficznych (sugerujących brak połączenia Popkowic z parafią kraśnicką) jest zapewne mylący ${ }^{30}$. Równie mylące może okazać się wnioskowanie oparte o sytuację własnościową z końca XIV wieku. Co prawda wydaje się, że Popkowice nieco dłużej, niż klucz kraśnicki, pozostawały w składzie domeny królewskiej (co mogłoby prowadzić do wniosku, że podlegały królewskiej parafii dzierzkowickiej), ale w istocie nie wiemy kiedy nastąpiła zmiana własności Popkowic. Dodatkowo, parafia w Stróży uchodzi za starszą od dzierzkowickiej ${ }^{31}$, co oznacza, że nawet przy przyjęciu założenia, że w którymś momencie Popkowice należały do tej drugiej, nie da się wykluczyć ich wcześniejszej podległości wobec kościoła w Stróży.

stensis (Decanatus: Urzędowviensis, Zawichostensis, Opatoviensis) opera commisaria R. D. Jacobi Piasecki decani Kilecensis, canonici Posnaniensis in Anno 1617 diebus Junii et Julii confecta (dalej: Wizytacja 1617), k. 15v.

${ }^{27}$ MPV, t. 1: ACA, vol. 1, s. 160.

${ }^{28}$ Wnuk, Dzieje parafii, s. 11.

${ }^{29}$ Anna Wnuk oparła swoją tezę na podanej przez Jana Długosza informacji, że z łanów osadzonego kmieciami folwarku w Skorczycach oddawano dziesięcinę snopową plebanowi z Dzierzkowic (DLB, t. 1, Kraków 1863, s. 342; t. 2, s. 513). Trzeba jednak zwrócić uwagę przede wszystkim na fakt, że informacja dotyczy nie Popkowic, lecz Skorczyc, a ponadto nie wiadomo w jakich okolicznościach doszło do powstania wspomnianego zobowiązania dziesięcinnego. Jest istotnym, że mimo obsadzenia przez kmieci łanów oddających dziesięciny, były to jednak łany, o których wyraźnie stwierdzono, że były łanami folwarcznymi. Prowadzi to do wniosku, że chodziło w tym przypadku o dziesięcinę swobodną, czyli taką, której odbiorcę wskazywał właściciel, a nie o łany, których przeznaczenie wskazywał biskup, $\mathrm{z}$ reguły w czasie powstawania nowej parafii. Można sobie bowiem wyobrazić sytuację, w której Skorczyce należały do parafii Stróża, której prawo patronatu do lat 70. XIV wieku posiadał zapewne monarcha. W momencie, gdy dobra królewskie znajdujące się w tej parafii trafiły w ręce Dymitra z Goraja, co pociągnęło za sobą przeniesienie jej centrum do Kraśnika i przeniesienie prawa patronatu na nowego właściciela, mogła nastąpić także zmiana odbiorcy dziesięcin z zapewne jeszcze w tym czasie królewskiego folwarku w Skorczycach. Prawo patronatu parafii Dzierzkowice nadal pozostało bowiem w rękach króla.

${ }^{30}$ Atlas Historyczny Polski. Mapy szczegółowe XVI wieku, Seria A, Nr 3: Województwo lubelskie w drugiej polowie XVI wieku, opr. S. Wojciechowski, Warszawa 1966.

${ }^{31}$ Henryk Grocholski uznawał parafię w Stróży za jedyną w archidiakonacie zawichojskim, co do której nie miał wątpliwości, czy istniała ona w XIII wieku: Grocholski, Sieć parafialna, s. 35; tenże, Powstanie archidiakonatu zawichojskiego i jego najstarsze kościoły do połowy XIV w., RH, 13 (1965) z. 2, s. 161. Ważne argumenty za istnieniem parafii w Stróży już w XIII wieku dodał ostatnio Rafał Dobroć: Dobroć, Pierwsze wieki, s. 66-68. 
Istnieją jednak przekazy źródłowe, które skłaniają do zadania pytań o możliwość istnienia Popkowic w okresie wcześniejszym niż XIV, czy 2. połowa XIII wieku. Przyjęcie takiej hipotezy oznaczałoby z kolei konieczność poszukania odpowiedzi na pytanie o ówczesną przynależność wsi do struktur administracji kościelnej. Zwracają uwagę przekazy z 2. połowy XV i 1. połowy XVI wieku informujące o tym, że dziesięciny z łanów kmiecych Popkowic oraz Skorczyc należały do scholastyka sandomierskiego ${ }^{32}$. Ponieważ duchowny ten był jednym z prałatów kolegiaty sandomierskiej, a przyjmuje się, że wyodrębnienie pięciu prebend rozumianych jako samodzielne prawnie i majątkowo beneficja, powiązanych z poszczególnymi prałaturami kapituły sandomierskiej nastąpiło najpóźniej w 1. połowie XIII wieku (zapewne przed 1223 r.) ${ }^{33}$, powinniśmy przyjąć, że także uposażenie scholasterii sandomierskiej określono najpóźniej w tym czasie. Prowadzi to do wniosku, że co najmniej w początkach XIII wieku powstało zobowiązanie dziesięcinne z pól Popkowic na rzecz scholastyka sandomierskiego, co oznaczałoby także, że istniała wtedy także interesująca nas wieś. Jednocześnie trzeba pamiętać o zanotowanej przez Jana Długosza wiadomości, że scholasteria sandomierska została uposażona $\mathrm{z}$ dochodów i dziesięcin kościoła parafialnego pw. św. Maurycego w Zawichoście ${ }^{34}$. Nawet jeśli nie przyjmiemy dosłownie tego przekazu i uznamy, że dochody zawichojskiego kościoła św. Maurycego weszły pierwotnie do wspólnego, jeszcze nierozdzielonego pomiędzy poszczególnych prałatów, uposażenia kolegiaty sandomierskiej, to jednak powinniśmy uznać, że stało się to w czasie reorganizacji tamtejszej kapituły i tworzenia podstaw jej uposażenia, a zatem zapewne jeszcze przed 1191 rokiem, być może w okresie po zjeździe w Łęczycy, który miał miejsce w $1180 \mathrm{roku}^{35}$. Po pierwsze pozwala to przesunąc istnienie zobowiązań dziesięcinnych, oraz samych Popkowic na 2. połowę XII wieku, po drugie wskazuje na wysoce prawdopodobną możliwość istnienia bardzo wczesnych związków omawianego przez nas terenu z kościołem św. Maurycego w Zawichoście.

Z kolei przyjęcie takiej hipotezy może prowadzić do bardzo ciekawych, lecz zarazem trudnych do pewniejszego podparcia silnymi argumentami, wniosków. Sam kościół św. Maurycego w Zawichoście od dawna interesował badaczy, a jego wezwanie, być może nawiązujące do przebiegu zjazdu gnieźnieńskiego z roku 1000, prowokowało do stawiania nieraz bardzo śmiałych hipotez dotyczących

${ }^{32}$ DLB, t. 1, s. 342; t. 2, s. 512-513; LR 1529, s. 400.

${ }^{33}$ L. Poniewozik, Prałaci i kanonicy sandomierscy w okresie średniowiecza, Torun 2004, s. 18. Najwcześniej poświadczonym źródłowo scholastykiem sandomierskim był Gumbert, występujący w 1224 roku (KDM, [t. 1]: 1178-1386, Kraków 1876, nr 10, s. 16; Poniewozik, Prałaci, s. 32, 176).

${ }^{34}$ DLB, t. 1 , s. 328.

${ }^{35}$ Już w 1191 roku kaplica (kościół) św. Maurycego w Zawichoście, wraz ze swoimi dochodami, została wymieniona wśród kaplic należących do uposażenia kolegiaty sandomierskiej: KDM, [t. 1], nr 2, s. 5 (ten sam dokument z błędną datą 1121 roku podany w Liber beneficiorum J. Długosza: DLB, t. 1, s. 402). Oznacza to, że wspomniane obiekty sakralne weszły w skład uposażenia kolegiaty jeszcze przed tą datą. Więcej na ten temat: Poniewozik, Prałaci, s. 17-18. 
czasów jego powstania ${ }^{36}$. W każdym razie nie wydaje się zbyt śmiałym wniosek, że świątynia ta istniała już w 1. połowie XII wieku. Najpóźniej na ten czas można także zapewne datować powstanie zobowiązań dziesięcinnych na rzecz wspomnianego kościoła, a co za tym idzie przyjmować istnienie samych Popkowic. Być może należałoby także rozważyć, czy nazwa wsi nie może sugerować nawet własności duchownej w początkowym okresie jej dziejów, choć w tej sprawie należy zachować daleko idącą ostrożnośćc 37 .

Analizując geograficzne rozmieszczenie powinności dziesięcinnych na rzecz scholasterii sandomierskiej, uchwytne dla 2. połowy XV, oraz dla 1. połowy XVI wieku łatwo zauważymy pewne prawidłowości ${ }^{38}$. Długosz, opisując dochody scholastyka sandomierskiego, wymienił kolejno następujące osady, z których pochodziły dochody tego prałata: Marszów (dzisiejszy Maruszów), Mistrzowice (wieś zanikła, leżąca na lewym brzegu Wisły na północ od Piotrowic), Ksany, Korczyn (czyli Stary Korczyn), Czyżów, Ostrów (dzisiejszy Ostrówek), Borów, Gościeradów, Kosin, Mniszek, Węglno (dzisiejszy Węglin), Pstrągi (osada zanikła, leżąca na południowy zachód od Borowa), Świątniki alias Świeciechowska Wola, Zdziechowice, Jastrzębia, Mąkosy, Goryń, Bartodzieje, Lisów, Lisów drugi, zwany Komorniki, Lisów trzeci, zwany Piaseczny (dzisiejsze Piaseczno), Jankowska Wola (zapewne dzisiejsza Żabia Wola na północny zachód od Jankowic), Michałów (zapewne Milaków), Skrzyszów, Giełzów, Kotuszów, Stara, Budków, Stawowice, Płasków, Sielec, Zawady, Bierwce, Wola Goryńska, Daleszewice, Wielka Wola, zwana Daleszowską, Niemojowice, Kupimierz, Sokołów, Przyłęk,

\footnotetext{
${ }^{36}$ Zygmunt Sułowski w kontekście rozważań dotyczących powstania najstarszego kościoła lubelskiego wspomniał o zawichojskim kościele św. Maurycego, którego wezwanie miało wyraźnie nawiązywać do przebiegu zjazdu gnieźnieńskiego z roku 1000. Badacz sugerował zatem, że początki świątyni mogły sięgać pierwszych lat XI wieku: Z. Sułowski, Przedlokacyjny Lublin w świetle źródet pisanych, w: Dzieje Lublina. Próba syntezy, t. 1, Lublin 1965, s. 35. W nowszej literaturze tezę o powstaniu tej świątyni, utożsamianej z odkrytym w latach 90 . ubiegłego stulecia obiektem określanym jako tetrakonchos, jeszcze w 1. połowie XI wieku podtrzymał Józef Dobosz: J. Dobosz, Monarchia i możni wobec Kościoła w Polsce do początku XIII wieku, Poznań 2002, s. 57, wraz przypisem 57, gdzie także ważna literatura na ten temat.

${ }^{37}$ Pewną analogią może być nazwa Mistrzowic występująca wśród wsi należących do uposażenia scholastyków, oraz nazwy Dziekanowice i Kantorowice należące do uposażenia kilku kapituł małopolskich. J. Szymański, Kanonikat świecki w Małopolsce od końca XI do połowy XIII wieku, Lublin 1995, s. 118-120 (zwłaszcza przypis 241). Spotykamy także Popowice położone tuż pod Zawichostem, oraz Popów nieco na północ od Świeciechowa. Obydwie te wsie, leżące na wschodnim brzegu Wisły także w późniejszym okresie były notowane jako własność duchowna.

${ }^{38}$ Uposażenie prałatów kapituły sandomierskiej badała ponad 20 lat temu Agnieszka Kurzydym: A. Kurzydym, Uposażenie prałatów kapituly sandomierskiej w XV-XVI wieku, Lublin 1996 (mps Archiwum KUL). Część jej pracy, poświęcona uposażeniu ziemskiemu i nieruchomościom, ukazała się drukiem: A. Kurzydym, Uposażenie ziemskie i nieruchomości prałatów kapituly kolegiackiej w Sandomierzu w XV-XVI w., RH, 45 (1997), z. 2, s. 19-37. Uposażenie ziemskie scholastyka sandomierskiego zostało przedstawione w artykule na s. 28-30, a najciekawsze dla naszych rozważań uposażenie dziesięcinne scholastyka i wicescholastyka omówiono jedynie w pracy pozostającej w maszynopisie od s. 62.
} 
Wójcin i Korytków ${ }^{39}$. Następnie zostały wymienione osady, z których pochodziły dochody wicescholastyka, czyli rektora szkoły sandomierskiej, utrzymywanego przez scholastyka sandomierskiego z jego własnych dziesięcin. Lista tych wsi, choć w kilku miejscach pozbawiona dokładniejszych informacji, obejmuje: Wyżnicę, Wyżniankę, Kraśnik, Stróżę, Bieliny (dzisiejsza Pasieka - część Kraśnika), Piaseczną Wolę (dzisiejsze Piaski - przedmieście Kraśnika), Grambinicę (osada zanikła, wchłonięta przez Kraśnik), Suchynię, Popkowice oraz Skorczyce ${ }^{40}$. Niemal tę samą listę osad, co prawda $\mathrm{z}$ niewielkimi korektami, ale prawie w tej samej kolejności, wymieniono opisując dochody scholastyka sandomierskiego w późniejszym o pół wieku od księgi Długosza rejestrze dochodów beneficjów diecezji krakowskiej $^{41}$.

W całej wymienionej wyżej sporej grupie miejscowości nas najbardziej interesują Czyżów, Ostrów, Borów, Gościeradów, Kosin, Mniszek, Węglno, Pstrągi, Świątniki i Zdziechowice, które zostały wymienione, jako osady położone okręgu sandomierskim i lubelskim, z których scholasteria miała dziesięciny snopowe ${ }^{42}$, oraz wsie, z których w czasach Długosza dochody pobierał wicescholastyk sandomierski. Lokalizując je na mapie bardzo łatwo dostrzegamy bowiem, że, poza Czyżowem, stanowią one zwarty kompleks złożony z osad usytuowanych bądź to bezpośrednio na prawym brzegu Wisły naprzeciwko Zawichostu (z wyjątkiem Świątnik), bądź to wzdłuż dróg biegnących z Zawichostu na wschód (Węglno, Zdziechowice) lub na północny wschód (Kosin, Mniszek, Gościeradów, grupa osad na Wyżnicą wokół Kraśnika i Stróży z najbardziej wysuniętymi na północ, położonymi już nad Urzędówką, Popkowicami i Skorczycami). Wszystko to nasuwa myśl, że może to być odbicie zasięgu najwcześniejszej fazy osadnictwa z początku XII, lub końca XI wieku na obszarach położonych na wschód od Wisły, znajdujących się w strefie wpływów ówczesnego ośrodka zawichojskiego. Wymienione osady mogły podlegać zawichojskiemu kościołowi św. Maurycego i w momencie uposażania tej świątyni zostać objęte obowiązkiem dziesięcinnym wobec niej. Oznaczałoby to, że pierwotnie Popkowice, wraz z innymi osadami oddającymi w XV i XVI wieku dziesięciny scholasterii sandomierskiej należały do parafii funkcjonującej właśnie przy tym obiekcie sakralnym. Pośrednim potwierdzeniem powyższego domysłu jest zapisana już przez Długosza informacja, że w połowie XV wieku, z powodu trudności i niebezpieczeństw, jakie stanowiła dla parafian Wisła, siedzibę tej parafii przeniesiono do usytuowanego na prawym brzegu tej rzeki Borowa ${ }^{43}$. Wspomniany zapis należy rozumieć zapewne $\mathrm{w}$ ten sposób, że wylewy rzeki utrudniały dostęp wiernym do kościoła parafialnego, zatem nowe centrum parafii ustanowiono w miejscowości położonej po tej samej stronie Wisły, co pozostałe osady wchodzące w jej skład.

Przyjęcie przedstawionej wyżej hipotezy oznaczałoby, że wszystkie parafie archidiakonatu zawichojskiego położone na wschód od Wisły stopniowo wyła-

\footnotetext{
${ }^{39}$ DLB, t. 1 , s. 329-339.

${ }^{40}$ Tamże, s. 339-

${ }^{41}$ LR 1529, s. 399-400.

${ }^{42}$ DLB, t. 1, s. 330-333.

${ }^{43}$ DLB, t. 1 , s. 329 ; t. 2, s. 492, 504.
} 
niały się z pierwotnej, bardzo rozległej parafii św. Maurycego. Mogłoby to thumaczyć fakt uchwytnego w późniejszych źródłach archidiakonatu zawichojskiego, ponieważ sam Zawichost już w XIV wieku miał okres swej świetności i największego znaczenia za sobą i nie wydaje się, by w tym okresie mógł być rozszerzany zasięg podlegającej temu ośrodkowi jednostki administracji kościelnej.

Parafia, obejmująca na początku bardzo duży obszar (najbardziej oddalone osady leżą około 40 kilometrów w linii prostej od Zawichostu), stosunkowo wcześnie musiała ulegać podziałom. Zapewne nie później, niż w połowie XIII wieku istniała już odrębna parafia $z$ ośrodkiem w Stróży i wiele wskazuje na to, że Popkowice znalazły się w jej składzie. Wzmożona aktywność monarchów w 2. połowie XIV wieku, która zmierzała do zagospodarowania terenów położonych na wschód od Wisły, między innymi poprzez politykę nadań ziemskich na tym obszarze, doprowadziła do zmian osadniczych oraz będącego ich skutkiem rozwoju sieci parafialnej. Reorganizacja własności królewskiej w okolicach Popkowic, zwłaszcza po przejęciu przez Dymitra z Goraja klucza kraśnickiego, mogła doprowadzić do przejściowego podporządkowania Popkowic parafii dzierzkowickiej, choć nie ma w tej kwestii wielu przesłanek. Ostatecznie, jak zaznaczyliśmy na początku naszych rozważań, na przełomie XIV i XV wieku powstała odrębna parafia popkowicka.

\section{Parafia Popkowice w XV i początkach XVI wieku}

Istnienie nowej parafii już w latach 20. XV wieku potwierdzają najwcześniejsze wzmianki o jej plebanie Janie, wspomnianym w 1424 i 1429 roku $^{44}$. W tym samym czasie (w 1428 r.) odnotowany został także scholarz z Popkowic Stanisław $^{45}$, co oznacza, że przy kościele popkowickim istniała już wtedy także szkoła parafialna. Wydaje się, że w tym okresie nie powinniśmy się spodziewać jakichkolwiek zaburzeń w funkcjonowaniu omawianej parafii. Pozostawała ona bowiem pod opieką możnych właścicieli Popkowic, należących do ścisłej elity politycznej państwa. Po śmierci Michała z Bogumiłowic i Czyżowa w końcu 1432 roku, jego majątek przejął syn - Jan z Czyżowa, który osiągnął najwyższe godności państwowe. W roku 1432 został starostą sandomierskim, na przełomie 1432 i 1433 roku kasztelanem sandomierskim, a w 1434 roku wojewodą sandomierskim, na którym stanowisku pozostawał do 1437 roku, gdy przeszedł na urząd wojewody krakowskiego. Następnie w latach 1437-1438 był wojewodą krakowskim, i w końcu, w latach 1438-1458 - kasztelanem krakowskim, czyli najwyższym dostojnikiem świeckim Królestwa Polskiego. Po wyjeździe Władysława Warneńczyka na Węgry w 1440 roku, został jego namiestnikiem w Małopolsce i na Rusi (wraz z Podolem), a urzędy te sprawował także w okresie bezkrólewia po bitwie pod Warną. Także po objęciu tronu przez Kazimierza Jagiellończyka w 1447 roku pozostawał

${ }^{4}$ J.A. Wadowski, Kościoly w Lublinie i diecezji lubelskiej, rękopis w Bibliotece Naukowej Polskiej Akademii Umiejętności i Polskiej Akademii Nauk w Krakowie, sygn. 2375, t. I, s. 204. Zapewne tego samego plebana Jana dotyczy wzmianka z 1432 roku: SHGWL, s. 188.

${ }^{45}$ SHGWL, s. 188. 
W najbliższym otoczeniu króla pozostając w ścisłej elicie politycznej państwa ${ }^{46}$. Po śmierci Jana z Czyżowa (w maju 1458 roku) jego rodzina nie potrafiła uniknąć problemów majątkowych. Po kilku latach zarząd odziedziczonych po Janie dóbr przejęła wdowa po nim Barbara, córka Piotra Odrowąża, wraz z małoletnim (urodzonym około 1448 roku) synem Janem z Czyżowa juniorem. Uważa się, że źle prowadzili oni gospodarkę w rozległych dobrach rodzinnych, popadli w długi i zaczęli stopniowo wyprzedawać majątek ${ }^{47}$. Z kolei bezpotomna śmierć Jana z Czyżowa juniora w pierwszych dniach 1476 roku, doprowadziła do przejęcia dziedzictwa przez potomków jego ciotki Wichny z Bystrzycy (siostry Jana z Czyżowa seniora) ${ }^{48}$. Nie obeszło się przy tym bez długich sporów majątkowych, przybierających formę procesów sądowych, przerywanych zawieranymi przez spadkobierców ugodami (w 1476 r.). Ostateczny podział dóbr po Janie z Czyżowa nastąpił dopiero w 1499 roku. Na mocy tego porozumienia Popkowice ze Skorczycami, a także m.in. leżące najbliżej tych wsi inne dobra Czyżowskich (dwie Rzeczyce, Zdziechowice) przypadły Hieronimowi Zaklice z Międzygórza ${ }^{49}$. Jak się jednak wydaje, Zaklikowie, którzy nabyli prawa do dziedziczenia poprzez małżeństwo Zakliki z Międzygórza z Katarzyną, córką Wichny z Bystrzycy, już wcześniej przejęli Popkowice, o czym mogą świadczyć zapisy zawarte w Liber beneficiorum Długosza ${ }^{50}$.

Te same przekazy są pierwszym kompletnym opisem parafii, wspominającym o istnieniu w Popkowicach drewnianego kościoła pod wezwaniem Św. Krzyża, oraz o przynależności Skorczyc do parafii popkowickiej. Także w tym miejscu wspomniano, że w Popkowicach (które miały łącznie 150 łanów gruntu, dwa młyny i dwie karczmy bez pól) pleban pobierał dziesięciny z 12 łanów folwarcznych o wartości 6 grzywien, a także miał dwa łany własnego pola, łąki, których używał dla swoich potrzeb, oraz meszne ${ }^{51}$.

Jak się wydaje, zarówno okręg parafialny, jak też uposażenie parafii popkowickiej nie ulegały zmianom w omawianym przez nas okresie. Co prawda w spisie podymnego z 1565 roku w składzie parafii Popkowice, poza Skorczycami

${ }^{46}$ Sochacka, Jan z Czyżowa, s. 84, 86, 91, 95, 99, 107, 110, 112n, 159n.

${ }^{47}$ Tamże, s. 217.

${ }^{48}$ Anna Sochacka skorygowała wcześniejszy błędny pogląd, oparty jeszcze na zapisach dawnych herbarzy, który zakładał, że dobra po Czyżowskich przeszły w ręce Zaklików przez małżeństwo Jana Zakliki z Agnieszką Ligęzą Czyżowską, córką kasztelana krakowskiego Jana z Czyżowa. Rzeczywiste powiązania rodzinne dwóch rodów badaczka przedstawiła m.in. na drzewie genealogicznym: Tamże, Aneks po s. 222. Warto zauważyć, że mimo upływu blisko ćwierćwiecza od wydania pracy A. Sochackiej poświęconej Czyżowskim, dawne przekonania wciąż podtrzymuje część publikacji.

${ }^{49}$ Tamże, s. 218-219. Treść porozumienia zapisano w aktach Metryki Koronnej: Matricularum Regni Poloniae Summaria (dalej MRPS), wyd. T. Wierzbowski, cz. 2: Iohannis Alberti regis tempora complectens (1492-1501), Warszawa 1907, nr 1365, s. 86.

${ }^{50} \mathrm{~W}$ spisanym wcześniej pierwszym tomie jako właściciel Popkowic i Skorczyc zanotowany został Jan Czyżowski (DLB, t. 1, s. 342), natomiast w sporządzonym zapewne po 1476 roku drugim tomie Długosz zapisał jako patronów kościoła w Popkowicach Jana Czyżowskiego, wspominając, że zmarł (mortuo), a także Jakuba i Zaklikę Międzygórskich (DLB, t. 2, 512).

${ }^{51}$ DLB, t. 1 , s. 342; t. 2, s. 512-513. 
zapisano także Zdziechowice ${ }^{52}$, ale jest to oczywiste nieporozumienie, co wynika choćby z położenia poszczególnych osad i odległości między nimi ${ }^{53}$. Ponadto wspomniany spis, jako rejestr podatkowy, nie miał na celu opisania rzeczywistego zasięgu parafii, lecz skuteczne odnotowanie powinności fiskalnych, a Zdziechowice od dawna były powiązane własnościowo z Popkowicami ${ }^{54}$. Pochodzący z 1529 roku szczegółowy opis uposażenia parafii popkowickiej także wykazuje wiele podobieństw do spisanego pól wieku wcześniej przekazu Długosza. Pleban pobierał w tym czasie dziesięciny snopowe tylko z łanów folwarcznych, a ich wartość wynosiła 6 grzywien. Ponadto z każdego półłanka pól kmiecych otrzymywał po pół kopy żyta, pół kopy owsa oraz pół kopy pszenicy, co dawało dochody o wartości 2 grzywien. Ostatnią częścią uposażenia parafii była kolęda, która przynosiła 1 grzywnę i 12 groszy dochodu. W sumie zatem pleban posiadał 9 grzywien i 12 groszy dochodu. Dodatkowo wciąż istniało zapewne pole plebańskie, skoro zapisano także, że zagrodnik odrabia dzień pańszczyzny tygodniowo ${ }^{55}$. Rejestry dochodów sporządzone w 1561 oraz w 1577 roku powtórzyły sumę 9 grzywien i 12 groszy dochodu parafii Popkowice ${ }^{56}$, ale było to mechaniczne przepisanie kwoty ustalonej w 1529 roku.

Samo przedstawienie zapisanych w źródłach kwot uposażenia parafii popkowickiej niewiele mówi o rzeczywistym statusie materialnym związanych z nią duchownych, choćby w tej przyczyny, że wartość pieniędzy ulegała z czasem zmianom. Aby zatem podjąć próbę oceny realnej wysokości dochodów plebana z Popkowic w 2. połowie XV i 1. połowie XVI wieku powinniśmy się posłużyć metodą stosowaną przez badaczy w takich sytuacjach. Należy przeliczyć szacowane kwoty dochodów z poszczególnych lat na trofy, które są wskaźnikiem siły nabywczej pieniądza, oznaczającym koszt normalnego dziennego wyżywienia, odpowiadającemu zapotrzebowaniu organizmu pracującego człowieka na 3.000 kalorii. Wartość trofy oczywiście ulegała zmianom na przestrzeni dziejów, ale przeliczanie na nią dochodów pieniężnych pozwala odpowiedzieć na pytanie o ich rzeczywistą wartość w konkretnym momencie ${ }^{57}$. Posługując się tą metodą

${ }^{52}$ Lustracja województwa lubelskiego 1565, wyd. A. Wyczański, Wrocław-Warszawa 1959, s. 41.

${ }^{53}$ Dodatkowo już w XV wieku Zdziechowice były ośrodkiem parafii, którą przeniesiono do lokowanego w XVI wieku Zaklikowa dopiero w późniejszym czasie. Por.: Atlas Historyczny Polski. Mapy szczegółowe XVI wieku, Seria A, Nr 3: Województwo lubelskie w drugiej połowie XVI wieku; A. Sochacka, Jan z Czyżowa, s. 199.

${ }^{54}$ Jan z Czyżowa już w 1458 roku wyznaczył swej żonie Barbarze rezydencje wdowią właśnie w Zdziechowicach. W 1499 roku znalazły się one, wraz z Popkowicami, w rękach Hieronima Zakliki. A. Sochacka, Jan z Czyżowa, s. 199, 219. Warto także zauważyć, że w rejestrze poborowym z 1531 roku w parafii Popkowice zanotowano, poza samą wsią parafialną, jeszcze tylko Skorczyce. Źródta dziejowe, t. 14: Polska XVI wieku pod względem geograficzno-statystycznym, opisana przez Adolfa Pawińskiego, t. 3: Małopolska, Warszawa 1886, s. 374.

${ }^{55}$ LR 1529, s. 452.

${ }^{56}$ LC 1561, k. 71v; LC 1577, k. 129v.

${ }^{57}$ Z. Żabiński, Systemy pieniężne na ziemiach polskich, Wrocław-Warszawa-Kraków-Łódź-Gdańsk 1981, s. 8-15. 
stwierdzamy, że w 2. połowie XV wieku 6 grzywien dawało 1.296 trof $^{58}$, a w 1529 roku 9 grzywien i 12 groszy - 1.025,64 trofy ${ }^{59}$. Jeśli uwzględnimy fakt, że w czasach Długosza odnotowano także inne dochody plebana (płynące z 2 łanów ziemi, oraz meszne), a w XVI wieku zapisano całkowitą ich wartość, dojdziemy do wniosku, że doszło do realnego i zapewne odczuwalnego spadku wartości dochodów plebana w Popkowicach. Gdyby przyjąć, że dochody z lat 60. i 70. XVI wieku miały wciąż taką samą wartość w groszach (co wynikałoby z dosłownego traktowania zapisów źródłowych z tego czasu), musielibyśmy przyjąć dalszy spadek realnych dochodów parafii popkowickiej, najpierw do 568, a następnie do 426 trof $^{60}$. Porównanie tych wartości z szacunkami dotyczącymi wcześniejszego okresu nie wymaga nawet komentarza.

Dochody parafii Popkowice na tle innych parafii archidiakonatu zawichojskiego leżących na wschód od Wisły w 1529 roku (dane dla tego roku są niemal kompletne i pozwalają na dokonywanie sensownych porównań) wskazuje, że była to parafia uposażona słabo. Tylko parafie Gościeradów, Zdziechowice, Słupia i Batorz posiadały wtedy niższe dochody, niż parafia w Popkowicach. Jak się wydaje wszystkie one zaliczały się do parafii powstałych stosunkowo późno na terenach także późno zasiedlonych. Pozostałe parafie tej części archidiakonatu zawichojskiego były uposażone lepiej, z reguły ich dochody były co najmniej kilkukrotnie wyższe od dochodów parafii popkowickiej ${ }^{61}$.

Także porównanie dochodów parafii popkowickiej z uposażeniem beneficjów zaliczanych do archidiakonatu lubelskiego pokazuje, że była to parafia stosunkowo biedna. Tylko dwie parafie tego archidiakonatu (Czemierniki nad Wieprzem i Kurów) miały taki sam poziom dochodów, a siedem innych (Niedrzwica, Wilków, Krasienin, Kiełczewice, Markuszów, Regów, Białka) - dochody niższe. Inne beneficja o niższych od parafii w Popkowicach (było ich 13) dochodach nie były beneficjami parafialnymi. Pozostałych 51 beneficjów archidiakonatu lubelskiego, w tym część nieparafialnych, była uposażona lepiej (czasem wielokrotnie), niż parafia Popkowice ${ }^{62}$.

Niskie dochody mogły być przyczyną zaburzeń w funkcjonowaniu parafii, o ile patron nie potrafił zachęcić duchownego do objęcia słabiej uposażonego beneficjum. Zapewne nie było problemu ze znalezieniem kandydata na objęcie funkcji plebana w Popkowicach dopóki prawo patronatu należało do możnych rodów (Czyżowskich, następnie Zaklików). Nawet biedniejsze beneficjum ple-

${ }^{58} \mathrm{~W} 1490$ roku 1 grzywna dawała 216 trof. Żabiński, Systemy pieniężne, Tabela 20, s. 56.

${ }^{59} \mathrm{~W}$ XVI wieku w polskim systemie pieniężnym nie występowała już grzywna. Uwzględnianie jej w księgach dochodów beneficjów wynika zatem z oparcia się na dawniejszym systemie, w którym grzywna oznaczała 48 groszy. Aby obliczyć wartość dochodów z 1529 roku należy je najpierw przeliczyć na grosze. 9 grzywien i 12 groszy jest równe 444 groszom, a grosz w latach 20. XVI wieku dawał 2,31 trofy. Z. Żabiński, Systemy pieniężne, Tabela 20, s. 56; Tabela 57, s. 102.

${ }^{60} \mathrm{~W}$ latach 60 . XVI wieku grosz dawał 1,28 trofy, zaś w następnej dekadzie już tylko 0,96 trofy. Żabiński, Systemy pieniężne, Tabela 57, s. 102.

${ }^{61}$ LR 1529, s. 426, 449-454, 456-457, 463-464.

${ }^{62}$ Pełne zestawienie dochodów beneficjów archidiakonatu lubelskiego z 1529 roku: Chachaj, Bliżej schizmatyków, s. 400-402. 
bańskie było atrakcyjne, zwłaszcza dla duchownych pochodzących z niższych warstw społecznych. Sytuacja mogła stanowić problem, gdy patronat znalazł się w rękach osób, które nie należały do możnowładztwa i nie dysponowały większymi dochodami. Brak źródeł nie pozwala na dokładniejsze naświetlenie tego problemu i udzielenie odpowiedzi na pytanie, czy miały miejsce w Popkowicach problemy z funkcjonowaniem parafii spowodowane jej niskimi dochodami ${ }^{63}$, ale odnotowany dla 1557 roku fakt kumulacji funkcji plebana w Popkowicach oraz prepozytury szpitalnej w Urzędowie przez księdza Stanisława ${ }^{64}$ mógł mieć przyczynę właśnie $\mathrm{w}$ niewielkich dochodach parafii popkowickiej.

W początkach XVI wieku, w niejasnych okolicznościach, Popkowice zmieniły właściciela. W latach 1507-1510 jako ich dziedzic notowany był chorąży i starosta lubelski Jakub Morawiec z Kolczyna herbu Powała ${ }^{65}$. Brak jakichkolwiek powiązań rodzinnych Morawców z Zaklikami, oraz fakt, że Hieronim Zaklika zmarł dopiero w 1508 roku wykluczają możliwość, że wspomniana zmiana własnościowa była skutkiem dziedziczenia. Zapewne doszło więc do sprzedaży Popkowic, które widocznie nie były atrakcyjne dla posiadających inne dobra Zaklików, a mogły stać się źródłem gotówki potrzebnej do planowanych być może w innych rejonach inwestycji. Tymczasem Morawcowie mogli wiązać jakieś plany z nabytymi dobrami, które leżały stosunkowo blisko ich dawnych posiadłości znajdujących się na prawym brzegu Wisły, niemal dokładnie na zachód od Popkowic $^{66}$. Dodatkowo pewne znaczenie dla pełniącego funkcję starosty lubelskiego Jakuba Morawca mógł mieć fakt, że w pobliżu znajdował się królewski Urzędów, a bezpośrednio na wschodzie parafia popkowicka sąsiadowała z kluczem wilkołaskim, należącym jeszcze w tym czasie do starostwa lubelskiego ${ }^{67}$.

Jak się wydaje Morawcowie także stosunkowo szybko zbyli dobra popkowickie. Już w 1522 roku jako dziedzic Popkowic wystąpił bowiem sędzia grodzki lubelski Mikołaj Bystram z Radlina ${ }^{68}$. Podobnie, jak w przypadku poprzednio opi-

${ }^{63}$ Być może odpowiedź na to pytanie przyniosłaby kwerenda w Archiwum Kapituły Kolegiackiej i Katedralnej w Sandomierzu, przede wszystkim w aktach archidiakonatu zawichojskiego i oficjalatu sandomierskiego. Należy to traktować jako postulat dla przyszłych badań.

${ }^{64}$ Archiwum Archidiecezjalne Lubelskie (AAL), sygn.. Rep 60 A 11: Akta konsystorza lubelskiego (Acta Consistorii Lublinensi Dioecesis Cracoviensi - dalej ACL), nr 11, k. 169v; Wadowski, Kościoły w Lublinie, s. 204.

${ }^{65}$ MRPS, cz. 4: Sigismundi I regis tempora complectens (1507-1548), vol. 2: Acta vicecancellariorum (1507-1535), Warszawa 1912, nr 8616, s. 17; nr 9661, s. 71; SHGWL, s. 105, 188, 205; Urzędnicy województwa lubelskiego XVI-XVIII wieku. Spisy, opr. W. Kłaczewski, W. Urban, pod red. A. Gąsiorowski, Kórnik 1991, s. 17, 50. Był to potomek, być może syn, Mikołaja Morawca, który w 1446 roku nabył dobra nad Wisłą (Rybitwy, Kolczyn, Opoczno, Ostrów) w powiecie urzędowskim przez małżeństwo dziedziczką tych posiadłości Anną córką Piotra z Sancygniowa. A. Sochacka, Własność, s. 91.

${ }^{66}$ Kolczyn, Opoczno, i Ostrów należały do parafii Rybitwy. Atlas Historyczny Polski. Mapy szczegółowe XVI wieku, Seria A, Nr 3: Województwo lubelskie w drugiej połowie XVI wieku.

${ }^{67}$ MRPS, cz. 4, vol. 2, nr 10682, s. 128; SHGWL, s. 260.

${ }^{68} \mathrm{~W}$ oparciu o wzmiankę w Metryce Koronnej czas występowania podsędka ziemskiego lubelskiego Mikołaja Bystrama jako dziedzica w Popkowicach określano w literaturze na rok 1524: MRPS, cz. 4, vol. 2, nr 13938, s. 299; SHGWL, s. 188. Tymczasem pisał się on z Popkowic już 
sanej zmiany właściciela, także kolejna, którą należy umieścić w 2., lub samych początkach 3. dekady XVI wieku, nie była dotąd dokładniej badana przez historyków. Tym razem jednak stosunkowo łatwo zrozumieć motywy, które mogły skłaniać nowych właścicieli do kupna Popkowic. Chodziło zapewne o dokupienie dóbr, które bezpośrednio sąsiadowały z ziemiami, które były w rękach rodu co najmniej od początków XV wieku ${ }^{69}$. Dziedzicem (zapewne synem) Mikołaja Bystrama był Paweł Bystram, występujący od 1527 roku jako podsędek lubelski, oraz właściciel Popkowic i Skorczyc ${ }^{70}$.

Od 1547 roku starania o zdobycie wspomnianych dóbr od bezdzietnego Pawła Bystrama, oraz jego żony Zofii z Mirowa Myszkowskiej, rozpoczął Mikołaj Rej. Nie znamy dokładnie okoliczności, ani szczegółów tych zabiegów, ale zakończyły się one sukcesem i uzyskaniem zapisów, które pozwoliły Rejowi wejść w posiadanie Popkowic po śmierci Bystrama w 1548 roku. Sprawa nieco się skomplikowała bo wdowa po Pawle Bystramie, mimo wcześniejszej zgody, próbowała podważyć umowę, uzyskując nawet w 1556 roku przed sądem grodzkim lubelskim wyrok nakazujący Mikołajowi Rejowi oddanie nabytych włości. Mimo to Rej utrzymał nabytek, a po śmierci Zofii (w tym samym roku) sam oskarżał przed sądami jej braci: kasztelana oświęcimskiego Krzysztofa, kasztelana wojnickiego Mikołaja, oraz Andrzeja i Stanisława Myszkowskich o zbrojny najazd, oraz ograbienie dworu i folwarku w Popkowicach ${ }^{71}$. Trwałe przejęcie przez Mikołaja Reja dóbr popkowickich, a wraz z nimi prawa patronatu parafii Popkowice, miało wkrótce przynieść tej ostatniej bardzo poważne skutki.

$\mathrm{W}$ tym miejscu należy poruszyć jeszcze jedną kwestię związaną z historią parafii Popkowice, mianowicie dzieje najwcześniejszego kościoła parafialnego $\mathrm{w}$ tej miejscowości. Sprawa nie była dotąd gruntowanie badana, ale w literaturze możemy spotkać mniej lub bardziej sensowne wypowiedzi odnośnie do popkowickiej świątyni, z reguły pozbawione odniesień do źródeł. Już przeszło pół wieku

w 1522 roku, gdy wystąpił jako sędzia grodzki lubelski: J.A. Wadowski, Kościoły lubelskie, Kraków 1907, s. 115.

${ }^{69}$ Sędzia grodu lwowskiego Bystram i jego brat Gotard, jako właściciele sąsiadującego z Popkowicami i Skorczycami bezpośrednio od północy Łopiennika notowani byli od 2. dekady XV wieku, a w położonym o kilka kilometrów na północny zachód od Łopiennika Radlinie Gotard potwierdzony jest jako dziedzic już od 1409 roku. Jak się wydaje następne pokolenie rodu reprezentował występujący w 2. połowie XV wieku komornik podkomorzego lubelskiego, podstoli i w końcu stolnik lubelski Mikołaj Bystram, którego zapewne powinniśmy uznać za ojca nabywcy Popkowic podsędka lubelskiego o tym samym imieniu. SHGWL, s. 138, 195; Sochacka, Własność, s. 97, 189; Urzędnicy, s. 53. Stolnik lubelski Mikołaj Bystram był zapewne młodszym synem Gotarda z Radlina, nazywanego też Radlińskim: M. Biskup, Radliński Gotard (Gotard z Radlina) h. Tarnawa (ok. 1430?-zm. 1480), PSB, t. 29, Wrocław-Warszawa-Kraków-Gdańsk-Łódź 1986, s. 704-705.

${ }^{70}$ Herbarz Polski ks. Kaspra Niesieckiego S.J. powiększony dodatkami z późniejszych autorów, rękopisów, dowodów urzędowych, wyd. J. N. Bobrowicz, t. 2, Lipsk 1839, s. 379.

${ }^{71}$ S. Paulowa, Materiaty do biografii Mikołaja Reja w Wojewódzkim Archiwum Państwowym w Lublinie, „Archeion”, 53 (1970) s. 90-91; Rey (Rej) Mikołaj z Nagłowic h. Oksza (1505-1569), PSB, t. 31, Wrocław-Warszawa-Kraków-Gdańsk-Łódź 1988, s. 200; Z. Guldon, J. Muszyńska, Mikołaj Rej. Poglądy ekonomiczne i działalność gospodarcza, w: Mikołaj Rej z Nagłowic. W pięćsetna rocznice urodzin, pod red. W. Kowalskiego, Kielce 2005, s. 161-162. 
temu pojawił się pogląd o możliwej budowie nowego kościoła w latach 20. XVII wieku, w związku z przywróceniem katolickiej parafii, po jej czasowym przejęciu przez protestantów ${ }^{72}$. O ile nie można z całkowitą pewnością wykluczyć podjęcia budowy, czy naprawy świątyni w tym czasie, o tyle wydaje się, że wspomniana wypowiedź opierała się na założeniu, że w czasie, gdy parafię przejęli kalwiniści doszło do zniszczenia wcześniejszego obiektu sakralnego. Zapewne skutkiem takiego samego toku myślenia (zapewne opartego na założeniu, że protestanci z założenia burzyli przejęte przez siebie świątynie) były wypowiedzi na temat losów kościoła popkowickiego, które można spotkać w nowej literaturze. Jedna z nich sugeruje, że Krzysztof Rej rozebrał katolicki kościół, by wkrótce potem zbudować protestancki zbór ${ }^{73}$. Nie próbując udowadniać absurdalności wspomnianych założeń musimy stwierdzić, że nawet stosunkowo pobieżna analiza znanych od dawna przekazów zmusza do dokonania zupełnie innej rekonstrukcji wydarzeń.

Należy zwrócić uwagę na fakt, że już bardzo dawno zauważono nastąpienie zmiany wezwania kościoła parafialnego, która nastąpiła w Popkowicach ${ }^{74}$. Poza najwcześniejszym, podanym przez Długosza, wezwaniem Św. Krzyża ${ }^{75}$, przekazy z ostatnich lat XVI wieku (1592 rok), oraz z początków XVII wieku (1617 rok) zgodnie informowały także o innym - św. Anny ${ }^{76}$. Pomijając omówienie trudnej do jednoznacznego rozstrzygnięcia kwestii, co w rzeczywistości mogła oznaczać zmiana wezwania kościoła ${ }^{77}$, zauważmy, że odnotowanie tego samego wezwania w 1592 i 1617 roku prowadzi do wniosku, że zapewne mamy do czynienia w obu przypadkach z tym samym obiektem sakralnym. W każdym razie nie ma jakichkolwiek, choćby minimalnych przesłanek pozwalających uznać, że miała miejsce budowa nowej katolickiej świątyni między 1592 a 1617 rokiem. Jednocześnie niemożliwym jest uznanie, że w 1592 roku wizytator odnotował wezwanie zboru hipotetycznie wzniesionego przez Krzysztofa Reja. Przyjmując nawet możliwość istnienia wezwania zboru u wyznawców kalwinizmu, co już wydaje się wątpliwe (w każdym razie źródła z XVI wieku nie przekazują takich informacji), zupełnie nie do przyjęcia jest wezwanie św. Anny. Jedynym możliwym wytłumaczeniem sytuacji notowanej przez źródła jest zatem przyjęcie, że wspomniane wezwanie nosił katolicki kościół w Popkowicach już w chwili, gdy został przejęty przez innowierców. Zmiana kościoła na zbór musiała nastąpić w 2. połowie XVI wieku,

${ }^{72}$ KZSP, t. 8, z. 9, s. 28.

${ }^{73}$ Wnuk, Dzieje parafii, s. 14.

${ }^{74}$ Grocholski, Sieć parafialna, s. 71.

${ }^{75}$ DLB, t. 1, s. 342; t. 2, s. 512.

${ }^{76}$ Wizytacja 1592, s. 43; Wizytacja 1617, k. 15v.

${ }^{77}$ Wydaje się, że jest to jeden z istotniejszych postulatów do badań w przyszłości. Sytuację zmiany notowanego w źródłach wezwania kościoła spotykamy wielokrotnie w okresie późnego średniowiecza, oraz pierwszych wiekach epoki nowożytnej. Przy tym niewątpliwie nie zawsze wspomniana zmiana wiązała się z budową nowego kościoła, lub czasowym przejęciem świątyni przez protestantów. W grę wchodzą bowiem choćby takie zjawiska, jak przemieszczenie wezwań ołtarzy bocznych, albo zmiana kolejności rozbudowanych wezwań pierwotnych, nie zawsze notowanych w całości. 
co zostało omówione niżej, a zatem już w 1. połowie XVI wieku świątynia popkowicka nosiła zapewne wezwanie św. Anny.

Podsumowując stwierdzamy, że albo w ostatnich dekadach XV wieku, albo w 1. połowie XVI wieku nastąpiła prawdopodobnie zmiana wezwania kościoła parafialnego w Popkowicach. Nie wiemy, jaka była przyczyna tej zmiany, ale zważywszy, że najstarszy budynek kościoła popkowickiego został wzniesiony na przełomie XIV i XV wieku, a także, że obiekt ten był drewniany ${ }^{78}$, powinniśmy brać pod uwagę możliwość podjęcia w 1. połowie XVI wieku budowy nowej świątyni. Być może także wśród przyczyn tego przedsięwzięcia należy uwzględnić ewentualność zniszczenia najstarszego kościoła w Popkowicach w czasie jednego z najazdów tatarskich z początku XVI wieku, których fakt, między innymi w okolicach Wilkołazu, został potwierdzony w źródłach ${ }^{79}$.

\section{Epizod reformacyjny}

Od dawna przyjmowano, że Mikołaj Rej około 1566 roku zamienił popkowicki kościół parafialny na kalwiński zbór ${ }^{80}$. W rzeczywistości nie mamy pewności, co do dokładnego czasu powstania zboru w Popkowicach ${ }^{81}$, nie potrafimy także stwierdzić jak długo funkcjonował, a okres, dla którego jest on potwierdzony źródłowo zamyka się w ćwierćwieczu między 1581 a 1605 rokiem $^{82}$. Źródła zgodnie

${ }^{78}$ DLB, t. 1 , s. $342 ;$ t. 2 , s. 512.

${ }^{79}$ MRPS, cz. 4, vol. 2, nr 10682, s. 128.

${ }^{80}$ Aleksander Kossowski podał wiadomość, że Mikołaj Rej zamienił kościół na zbór około 1566 roku: A. Kossowski, Protestantyzm w Lublinie i Lubelskiem w XVI-XVII w., Lublin 1933, s. 95 (na s. 97 zbór wymieniony, jako istniejący w XVI wieku bez bliższych odniesień czasowych, na s. w zbiorczej tabeli, jako istniejący w okresie 1550-1598 oraz 1598-1628). Tę samą wiadomość powtarzano też później: KZSP, t. 8, z. 9, s. 28; Wnuk, Dzieje parafii, s. 12, 14. Już pod koniec XV wieku w należącym do Mikołaja Bystrama Radlinie przebywał na służbie Biernat z Lublina, którego uważa się za jednego z prekursorów polskiej reformacji. Zapewne był wtedy nauczycielem Stanisława Bystrama, syna swego chlebodawcy, a zatem zapewne brata Mikołaja, późniejszego właściciela Popkowic: A. Grychowski, Na marginesie notatki autobiograficznej Biernata z Lublina, „Pamiętnik Literacki”, 52/4 (1961) s. 520-521. Trudno jednak upatrywać związku tego wydarzenia z powstaniem w XVI wieku zboru popkowickiego.

${ }^{81}$ Wątpliwości co do faktu ustanowienia przez Mikołaja Reja zboru w Popkowicach podnoszono w literaturze od dawna. Zwracano uwagę, że nie miał on ścisłych formalnych powiązań z kierownictwem ruchu reformacyjnego, początkowo nie brał nawet udziału w jego synodach, a później czynił to sporadycznie. O ile chętnie pozbawiał dochodów kościoły, których był patronem, a także brał z tych świątyń cenne przedmioty, o tyle nie przykładał się do budowy struktur organizacyjnych nowego wyznania w podległych sobie parafiach, ani nie spieszył się do utrzymywania protestanckich ministrów, ani do ponoszenia jakichkolwiek kosztów na potrzeby zborów. Rey (Rej) Mikołaj, s. 198.

${ }^{82}$ Według A. Kossowskiego zbór był wzmiankowany na licznych synodach od 1581 do 1606 roku, istniał także w okresie 1598-1627: Kossowski, Protestantyzm, s. 95, 155-156. Jednocześnie w innym miejscu (s. 184) badacz zaznaczył, że zbór popkowicki upadł w okresie 1598-1628. W czasie synodu dystryktowego we wrześniu 1581 roku minister z Popkowic Franciszek Jezierski został wybrany superintendentem. Był on jednak nadal ministrem w Popkowicach, co odnotowano w czasie następnego synodu w lipcu 1582 roku. Istnienie zboru w Popkowicach potwierdzają także 
informują jednak o trwałym upadku miejscowej parafii katolickiej, zawierając wskazówki pozwalające datować to wydarzenie na początek lat 60 . XVI wieku ${ }^{83}$. Jak się wydaje, taki stan rzeczy trwał przez kilka dekad, zarówno w czasach, gdy Popkowice należały do Krzysztofa Reja ${ }^{84}$, jednego z synów Mikołaja, jak też jeszcze jakiś czas później. Być może, to właśnie dopiero Krzysztof, bardziej aktywny od swego ojca w ruchu reformacyjnym, założył w rzeczywistości zbór w Popkowicach, którego później był patronem. Musiałoby to zatem nastąpić jakiś czas po śmierci Mikołaja Reja (która miała miejsce w 1569 roku), po uregulowaniu między jego synami kwestii majątkowych i dokonaniu podziału dziedzictwa. Stało się to w każdym razie przed 1582 rokiem, gdy Krzysztof wystąpił jako dziedzic Popkowic i Skorczyc ${ }^{85}$.

Dopiero w drugiej dekadzie XVII wieku miały miejsce działania zmierzające do odnowienia parafii w Popkowicach. Wydaje się, że powinniśmy wiązać ten fakt ze zmianą właściciela tej wsi. W 1617 roku po raz pierwszy notowany był jako kolator (czyli patron) parafii Jan Szornel ${ }^{86}$, który w latach 20. XVII wie-

akta odbytej w tym samym czasie wizytacji dystryktu lubelskiego. W lipcu 1586 roku wysłano na funkcję ministra w Popkowicach Krzysztofa Wielickiego. W październiku tego samego roku został on przeniesiony do zboru w Bełżycach, a na jego miejsce wyznaczono Jakuba Dzierżanowskiego. Z kolei Dzierżanowski był ministrem w Popkowicach jeszcze w kwietniu 1587 roku. W lipcu 1588 roku ministra Jana z Popkowic wysłano na ministra do Kliczkowic, a w październiku 1595 roku ministrem w Popkowicach został Paweł Kowalewski, wspomniany także na przełomie września i października 1600 roku. Ostatnia wzmianka świadcząca o istnieniu zboru w Popkowicach pochodzi z czerwca 1605 roku, gdy Mikołaj Orlicz z Popkowic został wysłany na ministra do ,jedlińskiego miasteczka": Akta synodów różnowierczych w Polsce, t. 3 (Małopolska 1571-1632), opr. M. Sipayłło, Warszawa 1983, s. VI, 44-45, 68, 70, 90-93, 174, 218, 272. W każdym razie oznaczałoby brak wzmianek o zborze popkowickim w latach 60 . i 70. XVI wieku, oraz po połowie 1. dekady XVII wieku.

${ }^{83}$ LC 1577, k. 129v z dopiskiem: prophanata; Wizytacja 1592, s. 43, gdzie wiadomość, że kościół został sprofanowany przez Mikołaja Reja przed 30 laty; Wizytacja 1598, s. 44 (Popkowice wymienione wśród sprofanowanych kościołów archidiakonatu zawichojskiego). Nieco inną datację należałoby przyjąć, idąc za zapisem zawartym w aktach wizytacji archidiakonatu lubelskiego z 1603 roku, gdzie wymieniono Popkowice (jako Popowice!) wśród sprofanowanych parafii dekanatu chodelskiego z informacją, że profanacji dokonał Rej przed 30 laty: AAL, sygn. Rep 60 A 96: Visitatio ecclesiarum et totius cleri in archidiaconatu Lublinensi Illustrissimi et Reverendissimi Domini D. Bernardi Maczieiowski Dei et Apostolicae Sedis Gratia Episcopi Cracoviensi Ducis Severiensis facta et conscripta per Deputatum Reverendum Thomasium Iossicium Canonicum Vislicensem Officialem Lublinensem in Anno MDCIII (dalej: Wizytacja 1603), s. 781. Ta ostatnia wiadomość może budzić wątpliwości odnośnie zawartych w niej wskazówek chronologicznych, zarówno ze względu na fakt, że powstała później, niż wymienione wcześniej akta wizytacyjne, a także ze względu na to, że wizytator profanację większości świątyń datował właśnie w ten sposób.

${ }^{84}$ Został on zapisany jako właściciel wsi w 1592 roku: Wizytacja 1592, s. 43.

${ }^{85}$ Urban, Rey (Rej) Krzysztof z Nagłowic h. Oksza (zm. 1625), s. 193. W czasie wizytacji zborów dystryktu lubelskiego w 1582 roku wizytator zanotował opinię ministra, że Krzysztof Rej z małżonką jest ,pilen słuchania”, ale także, że daje zły przykład poddanym, bo nie przystępuje do komunii i nie przymusza ich do słuchania kazań: Akta synodów, t. 3, s. 68.

${ }^{86}$ Wizytacja 1617, k. 15v; AKMK, Acta Episcopalia (dalej AEp), nr 41, k. 271; AAL, sygn.. Rep 60 A 20: ACL, nr 20, k. 171v; Wadowski, Kościoly w Lublinie, s. 204. Anna Wnuk w jednym 
ku był dziedzicem Popkowic, Skorczyc oraz Ostrowa (powstałego zapewne na gruntach Popkowic) $)^{87}$. Nie znamy przyczyn, ani przebiegu zmiany własnościowej wspomnianych dóbr, ale możemy się domyślać, że Krzysztof Rej sprzedał je pod koniec życia ${ }^{88}$. Nowy właściciel już w 1617 roku podejmował działania, które należy wiązać z przywracaniem do życia parafii katolickiej. Tak zapewne trzeba rozumieć jego ówczesne zabiegi dotyczące zmiany przynależności Popkowic do jednostek sądownictwa kościelnego ${ }^{89}$. Jan Szornel w 1625 lub 1629 roku na nowo uposażył popkowicki kościół parafialny, który odebrał kalwinistom. W tym czasie przy świątyni pojawił się też na nowo pleban ${ }^{90}$. Tym samym rozpoczął się kolejny

miejscu podała, że Jan Szornel w 1617 roku przywrócił kościół katolikom (Wnuk, Dzieje parafii, s. 12), w innym stwierdziła, że około 1617 roku wykupił (!) on świątynię i oddał ją wyznawcom katolicyzmu, a 19 marca 1625 roku także uposażył (tamże, s. 14). W nowszych pracach autorki znalazła się wiadomość, że Jan Szornel w 1617 roku nabył od Krzysztofa Reja Popkowice i Skorczyce, a następnie (bez żadnych odniesień czasowych), że wykupił kościół popkowicki z rąk protestantów, oddał go katolikom, oraz uposażył: A.U. Wnuk, Jerzy Szornel herbu Dołęa z Popkowic, sędzia ziemski lubelski i jego testament, „Rocznik Lubelskiego Towarzystwa Genealogicznego”, 4 (2012) s. 151. Nie wiadomo z jakich źródeł autorka zaczerpnęła podane przez siebie wiadomości, ale powoływała się na zapisy w aktach wizytacyjnych z 1617 roku (Wnuk, Dzieje parafii, s. 14).

${ }^{87}$ Rejestr poborowy województwa lubelskiego (powiat lubelski i urzędowski z r. 1626, ziemia tukowska z r. 1620), opr. J. Kolasa i K. Schuster, pod red. S. Inglota, Wrocław 1957, s. 75.

${ }^{88} \mathrm{~W}$ każdym razie przyjmuje się, że zmarł krótko po 29 września 1625 roku (Urban, Rey (Rej) Krzysztof, s. 193), co oznacza, że żył jeszcze w momencie, gdy bez wątpienia właścicielem Popkowic i Skorczyc był już Jan Szornel.

${ }^{89}$ Szerzej na ten temat niżej, przy omawianiu przynależności Popkowic do jednostek administracji kościelnej. Wydaje się, że wnoszone przez właściciela wsi, a zarazem patrona parafii prośby dotyczące przeniesienia Popkowic z oficjalatu sandomierskiego do lubelskiego miały na celu ułatwienie procedur związanych ze sprawami rozstrzyganymi przez sądy kościelne. Prawdopodobnie oceniano, że w razie konieczności rozpatrywania jakiejś sprawy przez sąd oficjała osobom związanym z parafią popkowicką łatwiej będzie załatwiać ją w Lublinie, niż w Sandomierzu. Ponieważ w omawianej epoce kwestie rozstrzygane przez sądy kościelne (tzw. causae spirituales) rozumiano znacznie szerzej, niż dzisiaj, a ponadto w gestii oficjała pozostawały np. kwestie rozwodowe, należy przypuszczać, że patron parafii w 1617 roku brał pod uwagę normalne funkcjonowanie społeczności katolickiej. Nie można wykluczyć, że impuls do podjęcia wspomnianych działań, zwieńczonych powodzeniem późną jesienią 1617 roku, było przeprowadzenie wizytacji kanonicznej latem tego samego roku.

${ }^{90}$ Wadowski, Kościoty w Lublinie, s. 204-205 (gdzie data 1629). Aleksander Kossowski powołując się na przechowywany w Bibliotece im. H. Łopacińskiego w Lublinie rękopis będący być może dokumentem erekcyjnym parafii Popkowice po odzyskaniu kościoła z rąk innowierców, poinformował, że właściciel Popkowic i Skorczyc Jan Szornel 19 marca 1625 roku nadał ówczesnemu plebanowi popkowickiemu Szymonowi Nastasowiczowi „pewną ilość zboża i ryby, oraz prawo mielenia zboża”. Kossowski, Protestantyzm, s. 154-155. Nie wiemy jak wyjaśnić tę sytuację. Być może któryś z badaczy błędnie odczytał datę roczną (stosunkowo łatwo pomylić cyfry 5 i 9 w rękopisie). Może także doszło do wystawienia dwóch różnych dokumentów zawierających opis uposażenia kościoła. Być może próbą wyjścia z tej niejasnej sytuacji była wprowadzająca dodatkowy zamęt informacja zamieszczona w Katalogu Zabytków Sztuki w Polsce (KZSP, t. 8, z. 9, s. 28), gdzie zapisano, że kościół został zwrócony katolikom przed 1625 rokiem, a uposażony w 1625 i 1658 roku (!). Anna Wnuk wydaje się opowiadać za datą podaną przez Kossowskiego: Wnuk, Dzieje parafii, s. 14. Kwestią otwartą pozostaje pytanie dlaczego nowy właściciel zwlekał 
okres dziejów parafii Popkowice, który wykracza już poza ramy chronologiczne niniejszego tekstu i należy już do nieco innej epoki, w której były wprowadzane w życiu Kościoła w Rzeczypospolitej reformy trydenckie.

\section{Przynależność parafii Popkowice do jednostek administracji kościelnej oraz jej plebani}

W omawianym okresie parafia Popkowice nieprzerwanie należała do archidiakonatu zawichojskiego diecezji krakowskiej, która wchodziła w skład metropolii gnieźnieńskiej ${ }^{91}$. Odnotowanie Popkowic $\mathrm{w}$ ramach archidiakonatu lubelskiego diecezji krakowskiej ${ }^{92}$ przez J. Długosza wynikało z faktu, że zaliczył on do tej jednostki administracyjnej wszystkie parafie diecezji krakowskiej położone na wschód od Wisły, nie wspominając wcale o archidiakonacie zawichojskim. Sprawa ta była poruszana w literaturze i choć część badaczy sprowadza ją do zwykłej pomyłki Długosza, być może należy rozpatrywać ją w kontekście hipotetycznego krótkotrwałego istnienia nieznanych nam podziałów administracyjnych diecezji krakowskiej w 2. połowie XV wieku ${ }^{93}$. Zapewne z innych przyczyn Popkowice zostały zaliczone do dekanatu chodelskiego archidiakonatu lubelskiego w czasie wizytacji z 1603 roku $^{94}$. Trzeba pamiętać, że byłą ona przeprowadzana w momencie odzyskiwania przez Kościół katolicki świątyń z rąk innowierców. Mimo, że proces odbudowy struktur kościelnych, zniszczonych w największym stopniu na terenie Lubelskiego w latach 60. i 70. XVI wieku trwał już wtedy od pewnego czasu, liczne obiekty sakralne były jeszcze w rękach przedstawicieli innych wyznań (najczęściej wyznawców kalwinizmu). Katoliccy wizytatorzy starali się odnotowywać te świątynie, zaliczając je do istniejących jednostek administracji Kościoła katolickiego, choć z powodu istnienia luk w strukturze parafialnej dokładny przebieg granic jednostek mógł być niejasny lub sporny. Dotyczyło to zwłaszcza parafii istniejących $\mathrm{w}$ granicach jednostek podziałów kościelnych, a z taką sytuacją mamy do czynienia w przypadku Popkowic. Wydaje się zatem, że informację z 1603 roku powinniśmy uznać albo za błąd, albo za świadome przekłamanie ze strony wizytatora reprezentującego archidiakona lubelskiego. U schyłku XVI wieku, w ramach reform wprowadzonych po soborze trydenckim, archidiakonat zawichojski został podzielony na dekanaty. Podziału dokonał biskup krakowski Jerzy kardynał Radziwiłł w grudniu 1598 roku, a parafia popkowicka znalazła się w składzie dekanatu urzędowskiego ${ }^{95}$. Występowała w nim odtąd stale ${ }^{96}$.

kilka lat z odnowieniem parafii w Popkowicach. Być może nie jest przypadkowa zbieżność czasowa między śmiercią Krzysztofa Reja a uposażeniem kościoła. Nie możemy wykluczyć, że transakcja sprzedaży wsi mogła zawierać jakieś uzgodnienia w tej kwestii (np. klauzulę przewidującą, że za życia poprzedniego właściciela nie zostanie odnowiona parafia katolicka).

${ }^{91}$ LR 1529, s. 452; LC 1561, k. 71v; LC 1577, k. 129v; Wizytacja 1592, s. 43; Wizytacja 1598, s. 44; Kowalski, Schematyzm, s. 116; Wizytacja 1617, k. 15v.

${ }^{92}$ DLB, t. 2, s. 512.

${ }^{93}$ Więcej na ten temat: Chachaj, Bliżej schizmatyków, s. 42-45.

${ }^{94}$ Wizytacja 1603, s. 781.

${ }^{95}$ Kowalski, Schematyzm, s. 107, 116.

${ }^{96}$ Wizytacja 1617, k. $15 \mathrm{v}$. 
Jeszcze wcześniej, zapewne pod koniec XIV wieku, diecezja krakowska została podzielona na jednostki administracji sądownictwa kościelnego, zwane oficjalatami terenowymi ${ }^{97}$. Choć zauważono liczne przesłanki przemawiające za tym, że w XV wieku część archidiakonatu zawichojskiego, do której należały Popkowice podlegała oficjalatowi terenowemu z ośrodkiem w Lublinie nie ma co do tego absolutnej pewności. Natomiast najpóźniej od około 1490 roku niewątpliwie teren archidiakonatu zawichojskiego znalazł się w zasięgu terenowego oficjalatu sandomierskiego ${ }^{98}$. W dniu 29 listopada 1617 r. parafia Popkowice na prośbę patrona Jana Szornela została przeniesiona z oficjalatu sandomierskiego do lubelskiego, z pozostawieniem jej w archidiakonacie zawichojskim ${ }^{99}$.

Obecnie jesteśmy w stanie wymienić pięciu plebanów pracujących przy parafii popkowickiej w omawianym przez nas okresie. Wydaje się, że ze względu na niewielką odległość czasową dzielącą wzmianki z lat 1424, 1429 i 1432, w których pojawiał się pleban z Popkowic Jan ${ }^{100}$ możemy uznać, że te zapisy odnoszą się do tej samej osoby. Następny pleban popkowicki został kilkakrotnie odnotowany w 1485 roku. Wbrew informacjom zawartym w części literatury nie nosił on imienia Jan, lecz Jakub ${ }^{101}$. W źródłach z XVI wieku odnotowano trzech kolejnych plebanów parafii Popkowice. W 1506 roku wystąpił pleban Maciej ${ }^{102}$, w 1529 roku beneficjum parafialne posiadał Jan z Kostomłotów ${ }^{103}$, zaś w 1557 roku plebanem w Popkowicach, a jednocześnie prepozytem szpitala urzędowskiego był Stanisław ${ }^{104}$.

Kwestię istnienia w Popkowicach instytucji spotykanych z reguły przy parafiach $\mathrm{w}$ omawianym czasie (szkoła parafialna, szpital parafialny), uzupełnienie listy oraz dokładniejsze omówienie osób związanych z popkowicką świątynią, zarówno pracujących przy niej duchownych (plebanów i wikariuszy), jak też stanowiących służbę kościelną, bardziej precyzyjne odtworzenie najstarszego uposażenia parafii, a także inne zagadnienia związane z funkcjonowaniem omawianej w niniejszym tekście parafii w pierwszych wiekach jej istnienia być może zostaną

${ }^{97}$ P. Hemperek, Oficjalat okręgowy w Lublinie XV-XVIII w. Studium z dziejów organizacji i kompetencji sądownictwa kościelnego, Lublin 1974, s. 72-73.

${ }^{98}$ Tamże, s. 96-99.

${ }^{99}$ AKMK, AEp, nr 41, k. 271-271v; AAL, sygn., Rep 60 A 20: ACL, nr 20, k. 171v-172v (wpisu do księgi oficjała dokonano 19 grudnia 1617 roku z podaniem błędnej wiadomości, że Popkowice zostały przeniesione $\mathrm{z}$ archidiakonatu sandomierskiego do archidiakonatu lubelskiego, $\mathrm{w}$ dalszej części wpisu zawarta jest jednak treść dokumentu biskupa krakowskiego Marcina Szyszkowskiego z prawidłowymi informacjami dotyczącymi zmiany przynależności do oficjalatów); Wadowski, Kościoły w Lublinie, s. 204; Hemperek, Oficjalat, s. 103.

${ }^{100}$ Wadowski, Kościoly w Lublinie, s. 204; SHGWL, 188.

${ }^{101}$ AAL, sygn. Rep 60 A 5: ACL, nr 5, k. 118; nr 6, k. 22, 33, 54v, 58. J. Wadowski miał zapewne na myśli tego plebana notując go pod 1485 rokiem, ale, z niejasnych przyczyn pomylił jego imię. Nie ma także źródłowego potwierdzenie odnotowany przez badacza pod tym samym rokiem pleban z Popkowic Mikołaj. Zapewne doszło w tym przypadku do pomyłki, bo zapisany obok plebana popkowickiego Jana Mikołaj był plebanem z Niedrzwicy. Wadowski, Kościoły w Lublinie, s. 204.

${ }^{102}$ AAL, sygn.. Rep 60 A 7: ACL, nr 7, k. 5v; Wadowski, Kościoły w Lublinie, s. 204.

${ }^{103}$ LR 1529, s. 452.

${ }^{104}$ AAL, sygn. Rep 60 A 11: ACL, nr 11, k. 169v. 
w przyszłości omówione w sposób bardziej szczegółowy. Pozostawiamy je jako postulat do dalszych badań, które mogą być przeprowadzone w oparciu o niewykorzystywane dotąd materiały źródłowe.

\section{BIBLIOGRAFIA}

\section{Źródła rękopiśmienne}

Archiwum Archidiecezjalne Lubelskie (AAL)

sygn. Rep 60 A 5, 7, 11, 20: Akta konsystorza lubelskiego (Acta Consistorii Lublinensi Dioecesis Cracoviensi), $\mathrm{nr}$ 5, 7, 11, 20

sygn. Rep 60 A 96: Visitatio ecclesiarum et totius cleri in archidiaconatu Lublinensi Illustrissimi et Reverendissimi Domini D. Bernardi Maczieiowski Dei et Apostolicae Sedis Gratia Episcopi Cracoviensi Ducis Severiensis facta et conscripta per Deputatum Reverendum Thomasium Iossicium Canonicum Vislicensem Officialem Lublinensem in Anno MDCIII.

Archiwum Krakowskiej Kapituły Katedralnej (AKKK)

sygn. tymcz. I-27 (sygn. dawna $\mathrm{nr} 5$ ): tzw. Liber contributionis (1561)

sygn. tymcz. I-26 (sygn. dawna nr 6): tzw. Liber contributionis (1577)

depozyt w Archiwum Kurii Metropolitalnej w Krakowie

sygn. nr 12: Visitatio ecclesiarum in archidiakonatu Zavichostensi AD 1598

sygn. nr 34 (AVCap 34): Acta visitationis ecclesiarum archidiakonatus Zavichostensis

(Decanatus: Urzędowviensis, Zawichostensis, Opatoviensis) opera commisaria R. D. Jacobi Piasecki decani Kilecensis, canonici Posnaniensis in Anno 1617 diebus Junii et Julii confecta

Archiwum Kurii Metropolitalnej w Krakowie (AKMK)

sygn. AV 1: Wizyta w archidiakonacie zawichojskim Andrzeja z Żarnowa wikariusza kolegiaty sandomierskiej z r. 1592 z polecenia Marcina Szyszkowskiego archidiakona zawichojskiego, kanonika krakowskiego, prepozyta iłżeckiego

Acta Episcopalia, $\mathrm{nr} 41$

\section{Źródla wydane i wydawnictwa źródłowe}

Akta synodów różnowierczych w Polsce, t. 3 (Małopolska 1571-1632), opr. M. Sipayłł, Warszawa 1983.

Długosz Jan, Liber beneficiorum dioecesis Cracoviensis, wyd. A. Przeździecki, t. 1, Kraków 1863; t. 2, Kraków 1864.

Kodeks dyplomatyczny Matopolski, wyd. F. Piekosiński, [t. 1]: 1178-1386, Kraków 1876; t. 3: 1333-1386, Kraków 1887.

Kowalski Waldemar, Schematyzm diecezji krakowskiej z tzw. kopiarza wiślickiego, „Archiwa, Biblioteki i Muzea Kościelne”, 81 (2004) s. 101-137.

Księga dochodów beneficjów diecezji krakowskiej z roku 1529 (tzw. Liber retaxationum), wyd. Z. Leszczyńska-Skrętowa, Wrocław-Warszawa-Kraków 1968.

Lustracja województwa lubelskiego 1565, wyd. A. Wyczański, Wrocław-Warszawa 1959.

Matricularum Regni Poloniae Summaria, wyd. T. Wierzbowski, cz. 2: Iohannis Alberti regis tempora complectens (1492-1501), Warszawa 1907; cz. 4: Sigismundi I regis 
tempora complectens (1507-1548), vol. 2: Acta vicecancellariorum (1507-1535), Warszawa 1912.

Monumenta Poloniae Vaticana, t. 1: Akta Kamery Apostolskiej, vol. 1: 1207-1344, wyd. J. Ptaśnik, Kraków 1913; t. 2: Akta Kamery Apostolskiej, vol. 2: 1344-1374, wyd. J. Ptaśnik, Kraków 1913; t. 9: Akta Kamery Apostolskiej, vol. 3: Ksiega kolektora papieskiego Piotra syna Stefana 1373-1375, wyd. S. Szczur, Kraków 1994.

Pomniki Dziejowe Polski, seria II, t. 10, cz. 2: Katalogi biskupów krakowskich, wyd. J. Szymański, Warszawa 1974.

Rejestr poborowy województwa lubelskiego (powiat lubelski i urzędowski z r. 1626, ziemia tukowska z r. 1620), opr. J. Kolasa i K. Schuster, pod red. S. Inglota, Wrocław 1957.

Zbiór dokumentów małopolskich, cz. 4: 1211-1400, wyd. S. Kuraś i I. Sułkowska-Kuraś, Wrocław-Warszawa-Kraków 1969; cz. 6: Dokumenty króla Władysława Jagietty $z$ lat 1386-1417, wyd. I. Sułkowska-Kuraś i S. Kuraś, Wrocław-Warszawa-Kraków-Gdańsk 1974.

Źródła dziejowe, t. 14: Polska XVI wieku pod względem geograficzno-statystycznym, opisana przez Adolfa Pawińskiego, t. 3: Matopolska, Warszawa 1886.

\section{Opracowania}

Atlas Historyczny Polski. Mapy szczególowe XVI wieku, Seria A, Nr 3: Województwo lubelskie w drugiej polowie XVI wieku, opr. S. Wojciechowski, Warszawa 1966.

Biskup Marian, Radliński Gotard (Gotard z Radlina) h. Tarnawa (ok. 1430?-zm. 1480), w: Polski Słownik Biograficzny, t. 29, Wrocław-Warszawa-Kraków-Gdańsk-Łódź 1986, s. 704-706.

Chachaj Jacek, Bliżej schizmatyków niż Krakowa. Archidiakonat lubelski w XV i XVI wie$k u$, Lublin 2012.

Chachaj Jacek, Najstarsze kościoły lubelskie, w: Ziemia - Człowiek - Sztuka. Interdyscyplinarne studia nad ziemia. Archeologia, historia, kultura, sztuka, red. U. Mazurczak, Lublin 2015, s. 375-412

Dobosz Józef, Monarchia i możni wobec Kościoła w Polsce do początku XIII wieku, Poznań 2002.

Dobroć Rafał, Pierwsze wieki parafii pod wezwaniem Wniebowzięcia Najświętszej Marii Panny w Kraśniku, Lublin 2015 (mps Archiwum KUL).

Dzieje Lubelszczyzny, t. 3: Stownik historyczno-geograficzny województwa lubelskiego w średniowieczu, opr. S. Kuraś, Warszawa 1983.

Graff Tomasz, Piotr Wysz, Piotr z Radolina, w: Encyklopedia Katolicka, t. 15, Lublin 2011, kol. 689-690.

Grocholski Henryk, Sieć parafialna archidiakonatu archidiakonatu zawichojskiego do końca XVI w., Lublin 1956 (mps Archiwum KUL).

Grychowski August, Na marginesie notatki autobiograficznej Biernata z Lublina, „Pamiętnik Literacki”, 52/4 (1961) s. 519-521.

Guldon Zenon, Muszyńska Jadwiga, Mikołaj Rej. Poglady ekonomiczne i dziatalność gospodarcza, w: Mikolaj Rej z Naglowic. W pięćsetna rocznice urodzin, pod red. W. Kowalskiego, Kielce 2005, s. 159-175.

Hemperek Piotr, Oficjalat okręgowy w Lublinie XV-XVIII w. Studium z dziejów organizacji i kompetencji sadownictwa kościelnego, Lublin 1974.

Herbarz Polski ks. Kaspra Niesieckiego S.J. powiększony dodatkami z późniejszych autorów, rękopisów, dowodów urzędowych, wyd. J. N. Bobrowicz, t. 2, Lipsk 1839. 
Katalog zabytków sztuki w Polsce, t. 8: Województwo lubelskie, pod red. R. Brykowskiego, E. Rowińskiej i Z. Winiarz, z. 9: Powiat kraśnicki, inwentaryzację przeprowadziły I. Galicka i E. Rowińska, Warszawa 1961.

Kossowski Aleksander, Protestantyzm w Lublinie i Lubelskiem w XVI-XVII w., Lublin 1933.

Krakowiak Kazimierz, Krótka historia parafii Św. Trójcy w Popkowicach (http://xoomer. virgilio.it/mpelak/dokumenty/histparpopko.htm, (dostęp 16.03.2017).

Kurzydym Agnieszka, Uposażenie prałatów kapituly sandomierskiej $w$ XV-XVI wieku, Lublin 1996 (mps Archiwum KUL).

Kurzydym Agnieszka, Uposażenie ziemskie i nieruchomości prałatów kapituły kolegiackiej w Sandomierzu w XV-XVI w., „Roczniki Humanistyczne”, 45 (1997) z. 2, s. 19-37.

Litak Stanisław, Powstanie organizacji parafialnej a rozwój osadnictwa $w$ ziemi lukowskiej XII-XVI w., „Roczniki Humanistyczne”, 48 (2000) z. 2 (specjalny), s. 283-307.

Nitecki Piotr, Biskupi Kościoła w Polsce. Stownik biograficzny, Warszawa 1992.

Paulowa Stanisława, Materiały do biografii Mikołaja Reja w Wojewódzkim Archiwum Państwowym w Lublinie, „Archeion”, 53 (1970) s. 83-98.

Perzanowski Zbigniew, Michat z Bogumiłowic, określany także z Chmielowa i z Czyżowa, w: Polski Słownik Biograficzny, t. 20, Wrocław-Warszawa-Kraków-Gdańsk 1975, s. $619-620$.

Poniewozik Leszek, Prałaci i kanonicy sandomierscy $w$ okresie średniowiecza, Toruń 2004.

[Red.], Rey (Rej) Mikołaj z Nagłowic h. Oksza (1505-1569), w: Polski Słownik Biograficzny, t. 31, Wrocław-Warszawa-Kraków-Gdańsk-Łódź 1988, s. 196-203.

Sochacka Anna, Jan z Czyżowa namiestnik Władysława Warneńczyka. Kariera rodziny Pótkozów w średniowieczu, Lublin 1993.

Sochacka Anna, Własność ziemska w województwie lubelskim w średniowieczu, Lublin 1987.

Sułowski Zygmunt, Przedlokacyjny Lublin w świetle źródeł pisanych, w: Dzieje Lublina. Próba syntezy, t. 1, red [ ] Lublin 1965, s. 30-42.

Szafran Przemysław, Rozwój średniowiecznej sieci parafialnej w Lubelskiem, Lublin 1958.

Szczygieł Ryszard, Lokacja miasta na prawie niemieckim i jego dzieje w czasach jagiellońskich, w: Dzieje Urzędowa, red. R. Szczygieł, M. Surdacki, Urzędów 2011, s. 55 100.

Szymański Józef, Kanonikat świecki w Małopolsce od końca XI do połowy XIII wieku, Lublin 1995.

Trawkowski Stanisław, Piotr z Radolina, zwany Wyszem, h. Laski (zm. 1414), w: Polski Stownik Biograficzny, t. 26, Wrocław-Warszawa-Kraków-Gdańsk-Łódź 1981, s. 422428.

Urban Wacław, Rey (Rej) Krzysztof z Nagłowic h. Oksza (zm. 1625), w: Polski Słownik Biograficzny, t. 31, Wrocław 1988-1989, s. 193-194.

Urzędnicy województwa lubelskiego XVI-XVIII wieku. Spisy, opr. W. Kłaczewski, W. Urban, pod red. A. Gąsiorowski, Kórnik 1991.

Wadowski Jan Ambroży, Kościoły lubelskie, Kraków 1907.

Wadowski Jan Ambroży, Kościoły w Lublinie i diecezji lubelskiej, rękopis w Bibliotece Naukowej Polskiej Akademii Umiejętności i Polskiej Akademii Nauk w Krakowie, sygn. 2375, t. I.

Wiśniowski Eugeniusz, Parafie w średniowiecznej Polsce. Struktura i funkcje społeczne, Lublin 2004. 
Wnuk Anna, Dzieje parafii Popkowice. 600 lat historii, Urzędów 2004.

Wnuk Anna Urszula, Jerzy Szornel herbu Dołęga z Popkowic, sędzia ziemski lubelski

$i$ jego testament, „Rocznik Lubelskiego Towarzystwa Genealogicznego”, 4 (2012) s. $151-175$.

Wroniszewski Jan, Nobiles Sandomirienses. Rody Dębnów, Janinów, Grzymałów, Doliwów i Powałów, Kraków 2013.

Żabiński Zbigniew, Systemy pieniężne na ziemiach polskich, Wrocław-Warszawa-Kraków-Łódź-Gdańsk 1981.

\section{ZARYS DZIEJÓW PARAFII POPKOWICE DO POCZĄTKÓW XVII WIEKU}

\section{Streszczenie}

Artykuł jest próbą syntetycznego omówienia najwcześniejszego okresu dziejów parafii Popkowice, od momentu jej powstania, do początków XVII wieku. W oparciu o przekazy źródłowe weryfikuje on poglądy występujące $w$ dotychczasowej literaturze dotyczącej poruszanego tematu. W tekście dokładniej przeanalizowano okoliczności powstania parafii popkowickiej, postawiono hipotezy dotyczące jej wcześniejszej przynależności parafialnej, omówiono jej dzieje w XV i XVI stuleciu, a także upadek w czasie reformacji i odnowienie w 1. połowie XVII wieku. W ostatniej części artykułu przedstawiono przynależność parafii Popkowice do jednostek administracji kościelnej oraz zestawiono możliwie kompletną na obecnym etapie badań listę plebanów popkowickich w omawianym okresie.

Słowa kluczowe: parafia Popkowice; kościół św. Maurycego w Zawichoście; scholasteria kapituły sandomierskiej; rozwój sieci parafialnej w archidiakonacie zawichojskim

\section{AN OUTLINE OF THE HISTORY OF THE POPKOWICE PARISH UNTIL THE EARLY 17TH CENTURY}

\section{Summary}

The article presents a synthetic discussion on the earliest period of the history of the parish of Popkowice, from the moment it was founded to the early 17 th century. Referring to the sources, the paper verifies the views present in the literature on the investigated subject. The text analyses in depth the circumstances of the foundation of the Popkowice parish, puts forward hypotheses on its previous parish affiliation, discusses its history in the 15th and 16th centuries as well as its decline during the Reformation and its revival in the first half of the 17th century. The last part of the article focuses on the affiliation of the Popkowice parish to the church administrative units and the list of the priests (as complete as possible at the present state of research) in Popkowice in the investigated period.

Keywords: the Popkowice parish; St Maurice Church in Zawichost; scholasteria of the Sandomierz chapter; the development of the parish network in the archdeaconry of Zawichost 